Hugoye: Journal of Syriac Studies, Vol. 13.2, 177-249

(C) 2010 by Beth Mardutho: The Syriac Institute and Gorgias Press

\title{
THE PHILOXENIAN GOSPELS AS RECONSTRUCTED FROM THE WRITINGS OF PHILOXENOS OF MABBUG ${ }^{1}$
}

\author{
J. EDWARD WALTERS \\ PRINCETON THEOLOGICAL SEMINARY
}

\begin{abstract}
This study presents the data for the text of the Philoxenian version for various Gospel passages as those texts can be reconstructed from the citations of Philoxenos. Several trends of translation technique become evident within the Philoxenian version: lexical changes for more "accurate" translation, attempts at more accurate and consistent translation of verb tense, lexical omissions and additions based on the Greek text, and alterations in the Syriac word order to reflect the
\end{abstract}

1 This project began as my M.A. thesis project directed by J.W. Childers: J. Edward Walters, "The Philoxenian Gospels as Reconstructed from the Exegetical Writings of Philoxenos of Mabbug," M.A. thesis (Abilene Christian University, 2009). I am grateful to Dr. Childers for chairing my thesis committee and for introducing me to textual criticism, to Syriac, and to Philoxenos. I also want to thank the other members of my thesis committee, Curt Niccum and Frederick Aquino, for their helpful suggestions in moving this project forward. And finally, I am grateful to guest editor Dr. David Michelson both for his encouragement and interest in my work, and to Dr. Andreas Juckel for his helpful comments and suggestions for improving my original thesis into the present publication. 
Greek. This translation technique confirms what is known about Greek-to-Syriac translation technique in the sixth-century during which there was an intentional movement toward a more word-forword translation. This technique was still in flux throughout the sixth-century until the creation of the hyper-literal Harclean version in the early seventh-century.

\section{INTRODUCTION}

\subsection{Philoxenos' Theological Motivation for the Translation Project}

Philoxenos, bishop of Mabbug (d. 523), ${ }^{2}$ is most well-known for the New Testament translation project that he sponsored in the first decade of the sixth century. ${ }^{3}$ Though his chorepiscopos, Polycarp, carried out the work of the translation, the new version produced has become known as the Philoxenian version. ${ }^{4}$

${ }^{2}$ For the most comprehensive introduction to Philoxenos, see André de Halleux, Philoxène de Mabbog: sa vie, ses écrits, sa theologie (Louvain: Imprimerie Orientaliste, 1963). For a more recent survey, see David Michelson, "Practice Leads to Theory: Orthodoxy and the Spiritual Struggle in the World of Philoxenos of Mabbug (470-523)" (Ph.D. Dissertation, Princeton University, 2007).

${ }^{3}$ According to the subscriptions of the Harclean version, the version was produced "in the year 819 of Alexander the Macedonian" (i.e. 507/8 CE). For the Syriac text and English translation of one such subscription, see William H.P. Hatch, "The Subscription of the Chester Beatty Manuscript of the Harclean Gospel," HTR 30, no. 3 (Jul. 1937), 149-150.

${ }^{4}$ Despite the fact that this version bears the name of Philoxenos, he did not carry out the actual translation. Tradition holds that the translation was carried out by Philoxenos' chorepiscopos, Polycarp. The attribution of the project to Polycarp is found in a letter of Moshe of Aggel. See I. Guidi, Rendiconti della Reale Accademia dei Lincei 4/2 (1886), 404. Cf. Sebastian Brock, "The Resolution of the Philoxenian/Harclean Problem" in New Testament Textual Criticism. Its Significance for Exegesis. Essays in Honor of Bruce M. Metzger, eds. E.J. Epp and G.D. Fee (Oxford: Clarendon Press, 1981), 325, n. 2. Though A. Mingana points out that there is a discrepancy in the tradition because another manuscript seems to suggest that Philoxenos carried out the translation himself. A. Mingana, "New 
Philoxenos sponsored this new translation because, in his opinion, the translators of the Peshitta had made errors, both intentional and accidental in their representation of the Greek text. This oftcited passage serves as Philoxenos' explicit reasoning for the creation of a new translation:

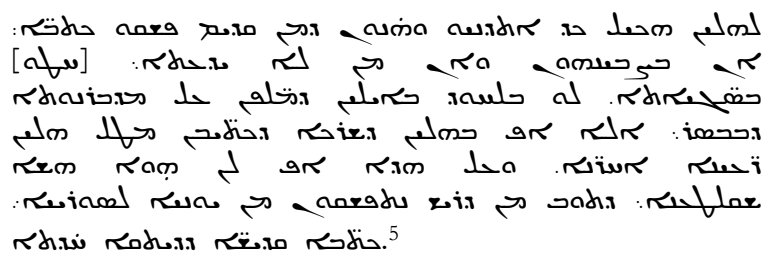

Thus when those who were of old applied themselves and translated the scriptures, whether by their will or as a result of ignorance, they erred in many [regards], not only in the things that are taught concerning the economy of the flesh, but also in the rest of the scriptures because of these other ways of thinking. And it was because of this that now we have taken the trouble 6 to translate the Holy Scriptures of the new covenant again from Greek into Syriac.

Moreover, in his discussion of the translation of Heb 5:7, we see even more explicitly that Philoxenos' desire for a new translation is fueled by the christological debates of the fifth- and sixth-centuries. He argues that the Peshitta's rendering of the phrase "in the days of his flesh" (صה حمir) was influenced by Nestorianism.7 Thus, the study of the Philoxenian version cannot be removed

Documents on Philoxenos of Hierapolis, and on the Philoxenian Version of the Bible," 9th series, vol. 19 (1920), 149-160.

5 André de Halleux, Pbiloxène de Mabbog, Commentaire du prologue jobannique (Ms. Br. Mus. Add. 14,534) CSCO 380 (versio) and 381 (textus), Scriptores Syri 165, 166 (Louvain: Secrétariat du CorpusSCO, 1977), 53. Hereafter CPJ.

${ }^{6} \mathrm{~S}$. Brock uses this translation for the phrase $2{ }^{2}$ and notes that this word is "frequently found in colophons of sixth-century MSS referring to the sponsors who had the MSS copied," in "The Resolution of the Philoxenian/Harclean Problem" in E.J. Epp and G.D. Fee, eds., New Testament Textual Criticism: Its Significance for Exegesis: Essays in Honour of Bruce M. Metzger (Oxford: Clarendon Press, 1981), 329.

${ }^{7}$ CPJ, 53. 
from the context in which it was conceived and created. However, the post-Chalcedonian christological debate is not the only context that shaped the text of the Philoxenian version.

\subsection{Greek-to-Syriac Translation Technique in the Sixth-Century}

It has been well-established that there was a significant change in Syriac-to-Greek translation technique taking place between the fifth- and seventh-centuries. This change in technique, characterized by Sebastian Brock as a move toward a more "wordfor-word" translation technique and away from a "sense-for-sense" technique, ${ }^{8}$ applies to works of Greek authors being translated into Syriac $^{9}$ and to translations of the Bible. ${ }^{10}$ Thus, just as we must

${ }^{8}$ Brock has a number of articles in which he takes up this topic. See especially Brock, "Aspects of Translation Technique in Antiquity," in Greek, Roman and Byzantine Studies XX (Durham, 1979), 69-87, repr. in Brock, Syriac Perspectives on Late Antiquity (London: Variorum Reprints, 1984); idem., "Greek into Syriac and Syriac into Greek," Journal of the Syriac Academy III (1979): 1-17, repr. in Brock, Syriac Perspectives; idem., "Limitations of Syriac in Representing Greek." in B. Metzger, The Early Versions of the New Testament: Their Origin, Transmission, and Limitations (Oxford: Clarendon Press, 1977), 83-98; idem., "Some Aspects of Greek Words in Syriac," in A. Dietrich, Synkretismus im syrisch-persischen Kulturgebeit (Göttingen: Vandenhoeck and Ruprecht, 1975), 80-108, repr. in Brock, Syriac Perspectives; and idem., "Towards a History of Syriac Translation Technique." in III Symposium Syriacum 1980: Les contacts du monde syriaque avec les autres cultures (Rome: Pont. Institutum Studiorum Orientalum, 1983): $1-14$.

${ }^{9}$ On this type of project, see D. King, The Syriac Versions of the Writings of Cyril of Alexandria: A Study in Translation Technique (Louvain: Peeters, 2008).

10 There has been some debate as to the role that the Philoxenian version played within this history. B. Aland argues that there was a particular strand of translation technique beginning with the Philoxenian version and ending with the hyper-literal Harclean version, and that some authors writing in the period between the production of these texts used the Philoxenian version for citations in works they were translating. B. Aland, "Die Philoxenianisch-Harklensische Übersetzungstradition," Le Muséon 94.3-4 (1981), 321-383; however, R.B. ter Haar Romeny disagrees with Aland's conclusion, arguing that the Philoxenian translation project 
consider the context of the christological controversies of the fifthand sixth-centuries when making observations about the Philoxenian version, so must we also consider the context of the changing Greek-to-Syriac translation technique taking place concurrently with its production. ${ }^{11}$ However, any attempt to compare the text of the Philoxenian version to other Scripture translation projects in order to determine the relationship between those texts is hindered by a glaring problem: the Philoxenian version does not actually exist as a text.

\subsection{The Philoxenian-Harclean Problem}

When Joseph White published the manuscript that he claimed to be the Philoxenian version, ${ }^{12}$ it seemed that there was finally an answer to the problem of the precise relationship between the Philoxenian and Harclean versions. ${ }^{13}$ We know from subscriptions of the Harclean version that Thomas of Harkel used the Philoxenian version in his own translation work, so when White's manuscript was published, it seemed to be a prime candidate because it is a Syriac biblical text with copious detailed marginalia

was not necessarily the first such translation project and, moreover, that authors writing after Philoxenos translated Biblical quotations for themselves rather than consulting the "authoritative" Philoxenian version. Bas ter Haar Romeny's response to Aland's article, "A PhiloxenianHarclean Tradition? Biblical Quotations in Syriac Translations from Greek," in Wout Jac. van Bekkum, Jan Willem Drijvers and Alex C. Klugkist, Syriac Polemics: Studies in Honour of Gerrit Jan Reinink (Louvain: Peeters, 2007), 59-76.

${ }^{11}$ For example, the translated works of Cyril of Alexandira must be taken into account because, as D. King argues, these translators "shaped Philoxenos' reading and theology," King, "New Evidence on the Philoxenian Versions of the New Testament and Nicene Creed," Hugoye 13.1 (2010): 9-30.

12 J. White, Sacrorum Evangeliorum versio Syriaca Pbiloxeniana cum interpretatione et annotationibus (Oxford: Clarendon, 1778).

${ }^{13}$ For a survey of the history of modern scholarship concerning the Philoxenian version, see D. King, Syriac Versions, 281-289; for more information on the Harclean version, see A. Juckel, "Introduction to the Harklean Text," in G.A. Kiraz, Comparative Edition of the Syriac Gospels, Vol. 1: Matthew (Piscataway: Gorgias Press, 2002), xxxi-lxxxii. 
that could represent Thomas' original notes correcting the Philoxenian text. The debate over whether or not White's text was actually the versio philoxeniana persisted for nearly two-hundred years, with scholars arguing both sides, until Sebastian Brock finally resolved the question once and for all. By comparing Scripture citations from Philoxenos' Commentary on the Prologue of John with the corresponding texts in both the Peshitta and the Harclean version, Brock concluded that the Philoxenian version is lost, save for the citations found in the writings of Philoxenos. ${ }^{14}$

Thus, the task stands before us now to attempt to reconstruct as much as possible of the text of the original Philoxenian version by examining the writings of Philoxenos, finding his Scripture citations, applying the appropriate methodology for discerning accurate citations, and providing support for the unique readings that may stand as the only surviving witness of a long lost biblical text. The present study is limited to the text of the Gospels, ${ }^{15}$ though the following criteria are applicable for the remaining documents of the NT as well.

\section{METHOD}

For a project of this kind, it is necessary to establish and employ methodologies both for discerning accurate citations of Scripture in patristic works and for concluding that a reading does in fact represent the text of the Philoxenian version. First, with respect to patristic citation methodology, it is not necessary to construct here an entire set of guidelines because other scholars have already

${ }^{14}$ Brock, "The Resolution of the Philoxenian/Harclean Problem," 341. For more evidence of text of the Philoxenian version, see J. Gwynn's discussion of the the possible Philoxenian version of the minor catholic epistles: J. Gwynn, "The Four Minor Catholic Epistles" in Remnants of the Later Syriac Versions of the Bible (Piscataway: Gorgias Press, 2005); idem., The Apocalypse of St. Jobn in a Syriac Version hitherto unknown (Dublin: Hodges, Figgis, and Co., 1897; repr. Amsterdam: Philo Press, 1981 and Piscataway: Gorgias Press, 2005); and for the Pauline corpus, see the volumes of the critical edition of the Syriac New Testament already in print: B. Aland and A. Juckel, eds., Das Neue Testament in Syrischer Überlieferung, Die Paulinischen Briefe, 3 Vols. (Berlin: Walter de Gruyter, 1991, 1995, 2002).

${ }^{15}$ More specifically, this study is limited to Matthew, Luke and John because Philoxenos almost never cites the Gospel of Mark. 
proposed such guidelines, ${ }^{16}$ nor is it necessary to recount what these scholars have said. Instead, we will offer here only the guidelines that are most applicable to the case of Philoxenos.

\subsection{Works of Philoxenos Considered}

One very important criterion for determining the accuracy of patristic citations is that of the genre of writing because, generally speaking, patristic authors are more likely to cite Scripture accurately in exegetical works and in theological treatises than they are in other styles of writing. Philoxenos was a prolific author, and his surviving works testify to the breadth of writing style: exegetical commentaries, theological treatises, homilies, ascetic instruction, and letters to various individuals and groups. Any attempt to reconstruct the text of the Philoxenian version must begin with the exegetical and theological materials. This is not to suggest that the other works are not possible repositories of Philoxenian readings; it is just more likely that Philoxenos would have been more careful about the wording of his Scripture citations in the works that deal specifically with arguments about Scripture. Thus, the present project began with the Gospel citations in Phiolxenus' two exegetical commentaries: the Commentary on the Prologue of John $(C P J)^{17}$ and the partial Commentary on Matthew and Luke (CML).18 Once these citations were gathered, they were compared with

${ }^{16}$ See especially G. Fee, "The Use of Greek Patristic Citations in New Testament Textual Criticism," $A N R W 26.1$ (1992): 256-262; and C. Osburn, "Methodology in Identifying Patristic Citations in NT Textual Criticism." NovT 47, no. 4 (2005): 313-343.

${ }^{17}$ See n. 4 above.

18 J.W. Watt, Pbiloxenos of Mabbug: Fragments of the Commentary on Matthew and Luke, CSCO 392 (versio) and 393 (textus), Scriptores Syri 171, 172. (Louvain: Secrétariat du CorpusSCO, 1978). Because of the transmission history of many of the fragments of CML, some have questioned its usefulness in reconstructing the text of the Philoxenian version. However, one MS (British Museum Add. 17126 = Watt's MS A) dates to the lifetime of Philoxenos (510/11 CE) and can thereby be considered a viable witness for citations without the danger of later scribal assimilation to more familiar texts. Moreover, de Halleux argues that this manuscript could be a product of the scriptorum at Mabbug sponsored by Philoxenos, Philoxène, 144-145. 
citations of the same verses that occurred in the other works of Philoxenos that met an additional external criteria: date of composition.

More specifically, when using the writings of Philoxenos to determine accurate Philoxenian citations, we must distinguish between works that pre-date and those that post-date the NT translation project and use them accordingly. ${ }^{19}$ 'Thus, Philoxenos' theological treatise on the Trinity ${ }^{20}$ was written after the project was completed and therefore may be considered as a possible source for Philoxenian readings, but Philoxenos' most extensive surviving work, The Discourses, ${ }^{21}$ was written earlier in Philoxenos' career and cannot be considered a reliable source. The writings of Philoxenos that post-date the translation project, but do not meet the genre criteria, may be used as reference for additional support, but unless they include explicit discussion of the wording of a particular text, it is too tenuous to base an argument for authentic Philoxenian readings on these writings. Thus, the present study makes use of Philoxenos' Letters to the Monks of Senoun (LMS), ${ }^{22}$ to compare citations that also occur in Philoxenos' other works, but it does not rely on any citations that occur only in LMS.

\subsection{Criteria for Assessing Citations}

Now that we have discussed "external" criteria for accurate Scripture citations in Philoxenos' works, we may now turn to a brief discussion of "internal" criteria. The first, and most reliable, criterion is that of explicit discussion of the wording of a text. Philoxenos offers such explicit discussions for only a precious few verses, but it is precisely these passages that give us some insight into the kinds of revisions in which Philoxenos was most

19 The two commentaries CPJ and CML were most likely being written concurrently with the translation project.

20 A. Vaschalde, Pbiloxeni Mabbugensis: tractatus tres de trinitate et incarnatione, CSCO 9 (versio) and 10 (textus), Scriptores Syri 9, 10 (Louvain: Imprimerie Orientaliste, 1955).

${ }^{21}$ E.A. Wallis Budge, The Discourses of Philoxenos, 2 Vols (London: Asher \& Co., 1894).

22 A. de Halleux, Philoxéne de Mabbog: Lettre aux moines Senoun, CSCO 231 (versio) and 232 (textus), Scriptores Syri 98, 99 (Louvain: Secrétariat du CorpusSCO, 1963). 
interested. ${ }^{23}$ This criterion is the only one that can provide absolute certainty that we have the unique Philoxenian reading, but there are other criteria that can provide a high degree of certainty for other verses.

A second internal criterion for accurate Philoxenian citations is multiple occurrences of a citation in the same form. If a citation in Philoxenos' works contains a variant from the reading of the Peshitta and that variant is attested in another citation elsewhere, we can conclude with a high degree of certainty that this reading represents the text of the Philoxenian version. However, when a citation occurs multiple times in different forms, this criterion is not necessarily helpful. ${ }^{24}$

The third internal criterion is an expressed intent to cite without an explicit discussion of the wording. This intent can be expressed with either the Syriac citation marker 7 or with some kind of introductory formula like - איר ("[Someone] said") or - תמב ("it is written"). As with many patristic authors, this criterion does not provide absolute certainty. That is, Philoxenos displays a varied use of such introductory markers. However, my research in the Philoxenian Gospels shows that Philoxenos' use of these introductory formulae are generally reliable enough to be considered part of the argument for whether or not a citation is accurate. ${ }^{25}$ However, there is one additional problem with the use of these introductory formulae: Philoxenos uses them with equal frequency with unique citations from the Philoxenian version and citations that are equivalent to the Peshitta reading. Thus, while these formulae are reliable for a high probability of accuracy, they

${ }^{23}$ In the present study, see the discussion below of Mt. 1:1 and 1:18. However, Philoxenos also explicitly discusses the translation of Rom 1:3, Heb 5:7, and Heb 10:5. See de Halleux's discussion of these passages in Philoxène, 123-124.

${ }^{24}$ For a prime example of this, see the discussion of Lk 1:35.

25 Of those 61 uses of $\mathbf{d}$ found in CPJ and MS A of CML, 59 of them $(96.7 \%)$ occurred with an accurate citation of either the Philoxenian version or the Peshitta. Similarly, Philoxenos' use of other introductory formulae is relatively reliable: 28 of $33(84.8 \%)$ citations that include such formulae are accurate citations of either the Philoxenian version or the Peshitta. For more on Philoxenos' use of these introductory formulae, see Chapter 4 of my thesis; Walters, "The Philoxenian Gospels," 126-130. 
are not reliable for distinguishing between readings of the Philoxenian version and the Peshitta. Thus, Philoxenos' use of introductory formulae may be used to an extent to determine the text of the Philoxenian version, but it should not be the only criterion upon which one bases the argument for a unique Philoxenian reading.

A fourth criterion is the relationship of the text found in the citation to the texts of the Peshitta and the Harclean version. Following Zuntz' original claim that the Philoxenian version was a "halfway house" between the Peshitta and Harclean version ${ }^{26}$ and Brock's conclusion in support of this claim, ${ }^{27}$ it is reasonable to assume that unique Philoxenian readings will, in various ways, resemble aspects of both texts. That is, some readings of the Philoxenian version will agree with the Peshitta over and against the Harclean version, and some readings that make revisions to the Peshitta text will agree with the revisions found in the Harclean version. 28 We know that Thomas of Harkel made use of Philoxenos' translation in his own work, so it is reasonable to conclude that citations that differ from the Peshitta but agree with the Harclean version have a high probability of representing the text of the Philoxenian version. ${ }^{29}$

A final internal criterion for determining an accurate Philoxenian citation is the translation technique of Philoxenos as established in other citations determined to be accurate. In other

26 G. Zuntz, The Ancestry of the Harklean New Testament, British Academy Supplemental Papers, no. 7 (London: The British Academy, 1945).

27 Brock, "The Resolution of the Philoxenian/Harclean Problem," 341.

${ }^{28}$ For example, while the Philoxenian version frequently matches the Harclean version in rearranging the Syriac word order to match Greek word order, it also consistently differs from the Harclean version on the addition of the possessive - x to represent a form of the Greek pronoun $\alpha \hat{\tau} \tau \tilde{v}$.

${ }^{29}$ In such cases, is not necessary to argue that Philoxenos or Polycarp were the originators of such unique readings as they may have known of these revisions from other translation projects. But we are concerned here only with determining the text of the Philoxenian version, and originality is not a criterion for accurate Philoxenian citations. 
words, if there is a unique reading that occurs only once and does not meet the above criteria, we may ask the question: Does this revision match the kind of revisions found in other Philoxenian citations? Or, if the revision does not match another citation, we may also ask: Based on the revisions found in other Philoxenian citations, is it reasonable to conclude that the Philoxenian version might have included this reading? This criterion is highly tenuous and should be used only with the utmost care and a fair dose of skepticism, but that does not mean that it cannot be applied in some instances.

\section{Presentation of the Data}

Based on the criteria outlined above, the present study seeks to present the unique readings of the Philoxenian version $(\mathrm{Ph})$ that can be reconstructed based on the accurate Scripture citations in the works of Philoxenos. The text of these citations is presented along with the corresponding texts of the Peshitta $(\mathrm{P})$ and Harclean version $(\mathrm{H}) .^{30}$ For reference, the Greek text $(\mathrm{G})^{31}$ is also included for each citation. The use of brackets [ ] around a word indicate that there is some question about the inclusion of that word within the text of $\mathrm{Ph}$. The discussion following the verse will indicate the reasons for uncertainty.

30 The texts of $\mathrm{P}$ and $\mathrm{H}$ presented in this study are those found in G. Kiraz, Comparative Edition of the Syriac Gospels: Aligning the Sinaiticus, Curetonianus, Peshitta and Harklean Versions, 4 Vols (Piscataway: Gorgias Press, 2004), though the Philoxenian readings were also compared with the textual variants listed in P.E. Pusey and G.H. Gwilliam, eds. Tetraenangelium Sanctum (Oxford: The Clarendon Press, 1901); repr. as Tetraenangelium Sanctum: The Fourfold Holy Gospel in the Peshitta Syriac Version with Critical Apparatus (Piscataway: Gorgias Press, 2003).

31 The Greek text shown is that of the 27th edition of Nestle-Aland. However, where applicable I have included textual variants from the Greek tradition. 


\subsection{Philoxenian Gospel of Matthew}

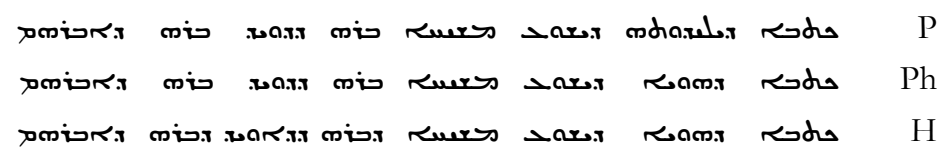

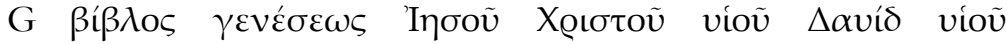

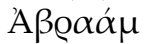

The text of Matthew 1:1 presented above is one of the few readings that we may attribute to the text of the Philoxenian version with absolute certainty because Philoxenos explicitly discusses the deficient translation of this passage as found in the text of the Peshitta and proposes his own translation. Philoxenos cites this passage six times: three of the six include the entire verse ${ }^{32}$ and the other three contain the first half of the verse. ${ }^{33}$ Philoxenos expresses an intent to cite with the citation marker $>0$ in both of the full length citations that include the text of $\mathrm{Ph} .{ }^{34}$ In the third citation that contains the whole verse, Philoxenos provides the text of the Peshitta version, which he introduces with the phrase, "[These things] now stand in the Syriac [version, i.e., the Peshitta]"

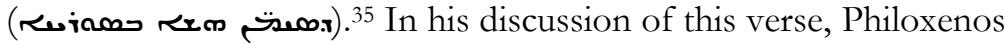
argues that the translation of $\mathrm{P}$ is inadequate because the Greek word $\gamma \varepsilon v \varepsilon \varepsilon \varepsilon \omega \varsigma$ should be translated as rom rather than modare.r. ${ }^{36}$ Brock asserts that Philoxenos' motivation behind this revision is "manifestly christological," because "in his polemic against the Antiochene theologians, [Philoxenos] wishes to associate the genesis of these passages with John 1:14." ${ }^{37}$ Whether or not Philoxenos was aware of another translation using rom rather than modare.r is not clear; but it is clear that the Philoxenian translation shows a preference for words built from the stem ram

32 CPJ 41.10-11; 42.18-20; 49.17-18.

${ }_{33}$ CPJ 47.13; 50.11-12; 52.12-13.

${ }^{34}$ CPJ 41.10-11; 49.17-18.

35 CPJ 42.18-20.

${ }^{36}$ CPJ 41-43. It also appears that Philoxenos made a mistake in his understanding of the meaning of the Greek words involved, Brock, "Resolution of the Philoxenian/Harclean Problem," 328.

${ }^{37}$ Ibid., 329. 
rather than words built from at, as evidenced by Matt 1:1 as well as the next passage. ${ }^{38}$

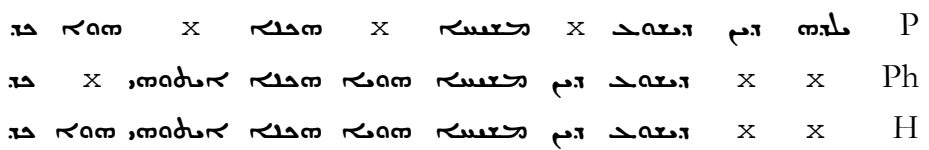

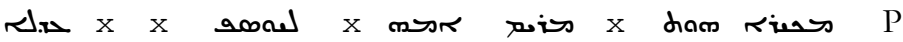

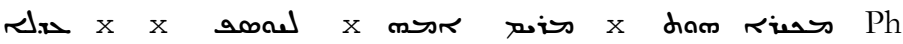

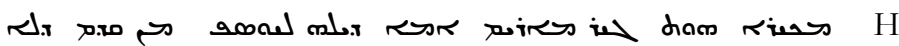

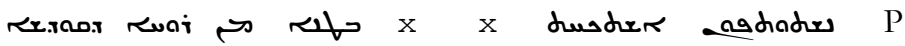

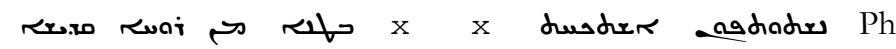

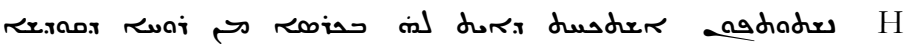

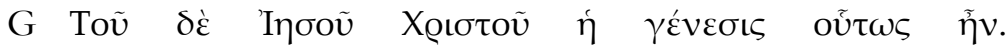

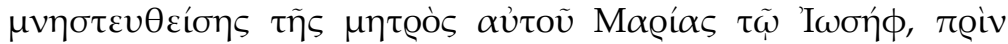

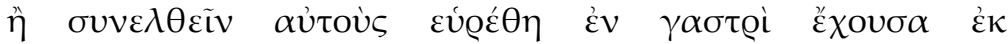

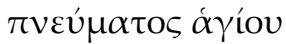

Philoxenos cites all or part of Matt 1:18 twelve times, ${ }^{39}$ and he introduces two of these citations with introductory formulae: , d a את ("And Matthew said") ("[He] wrote that...").41 The discussion of Matt 1:1 above also applies to 1:18 as Philoxenos mentions both verses as examples of the inadequacy of the Peshitta translation. ${ }^{42}$ Yet again, Philoxenos argues that the word r. should be removed from the translation and replaced by rom. ${ }^{43}$

38 Outside the Gospels, we also see the preference for ram words in Romans 1.

${ }^{39}$ Full: CPJ 41.11-14; 43.4-7; 44.12-15; Partial: CPJ 41.20-21; 42.2021; 43.24-25; 47.14; 50.12-14; 52.13-14; 120.1-2; 227.5-6; 236.11-12.

40 CPJ 47.14; 50.12-14.

${ }^{41}$ CPJ 236.11-12.

${ }^{42}$ CPJ 42-43.

43 Zuntz also found this revision in the text of Matt 1:18 in Tractatus Tres and commented that this word choice was "one of philosophical rather than of biblical flavour," The Ancestry of the Harklean Version, 45. It is interesting, however, that Zuntz does not comment on the possible theological connotations of this lexical change. 
As with Matt 1:1, Philoxenos quotes the text of $\mathrm{P}$ and then provides his own translation. ${ }^{44}$ Philoxenos replaces the verb rom at the end of the first phrase with the verbal phrase , madur, likely in an attempt to better represent the Greek imperfect verb ๆ๊v. All seven of Philoxenos' citations that include this portion of the verse include ,madur, ${ }^{45}$ and this reading is retained in the text of $\mathrm{H}$. Moreover, given the attention that Philoxenos dedicates to the proper wording of this verse, it is safe to assume that he would have cited this verse with great care. Thus, it is reasonable to conclude that the text presented above is the accurate reading of $\mathrm{Ph}$.

$1: 20$

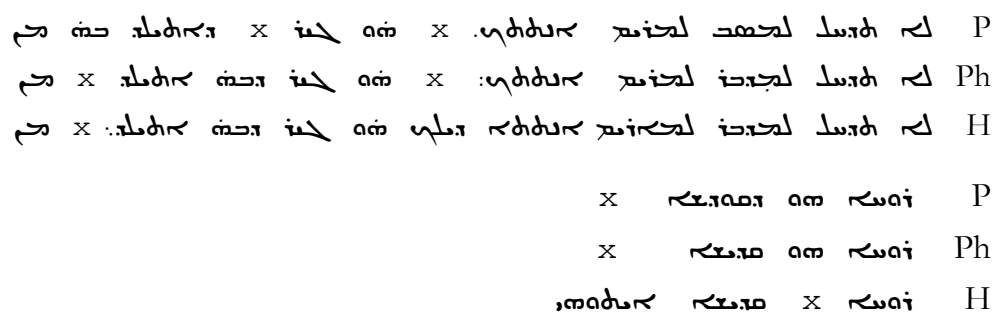

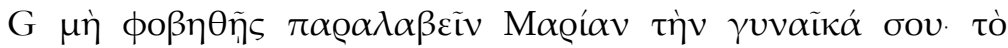

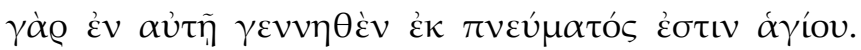

In two citations ${ }^{46}$ of this verse, the text of $\mathrm{Ph}$ renders the Greek word $\pi \alpha \varrho \alpha \lambda \alpha \beta \varepsilon \tilde{\varepsilon} v$ as ivis though a third citation ${ }^{47}$ retains

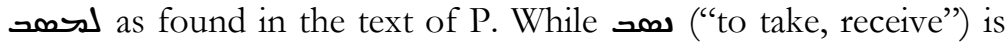
generally a better word-for-word translation than ix ("to lead, guide") for the Greek word $\pi \alpha \varrho \alpha \lambda \alpha \beta \varepsilon \tilde{\imath} v$, the idiom rodur iv means "to take a wife" or "to marry." 48 It is possible that the text of

${ }^{44}$ CPJ 42.20-21.

${ }^{45}$ None of the citations in CPJ contain rom here, but two of the citations of this verse from Tractatus tres de Trinitate, which are otherwise identical, include rom in addition to ,madur.

${ }^{46}$ CPJ 227.7-8; CPJ 41.15-16.

${ }^{47}$ CPJ 41.21-22.

$48 \mathrm{~J}$. Payne Smith, A Compendious Syriac Dictionary (Eugene: Wipf and Stock, 1999), 82; M. Sokoloff, A Syriac Lexicon (Winona Lake: Eisenbrauns; Piscataway: Gorgias Press, 2009), 271. 
$\mathrm{Ph}$ included Sריכה and Philoxenos simply reverted to the Peshitta reading sos in one citation by accident, but this seems unlikely because the two readings occur within just a few lines of each other. However, whether or not the use of is reasonable to conclude that the text of $\mathrm{Ph}$ reads ivis for two reasons: 1) Philoxenos cites the full verse with this reading twice; and 2) this reading is also found in $\mathrm{H}$. The text of $\mathrm{H}$ moves the

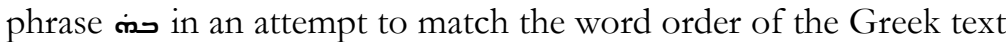

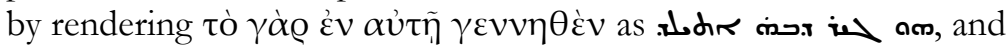
this word order also occurs once in $\mathrm{Ph} .{ }^{49}$ However, in the other two full citations and in an additional partial citation of this verse,

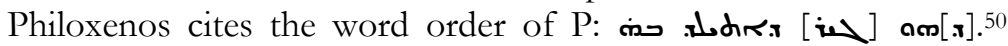
Only one of the four citations includes in, and it is the same citation that matches the reading found in $\mathrm{H}$. So, in three citations, Philoxenos includes the word order of $\mathrm{P}$, but in one citation his wording matches that of $\mathrm{H}$ exactly. There is also some question as to whether or not the text of $\mathrm{Ph}$ includes the prefix $-\boldsymbol{x}$ in this phrase. The three citations that match the Peshitta word order also include the - $\boldsymbol{x}$, but the citation that matches the text of $\mathrm{H}$ does not include it. The various forms of the citation of this verse and the fact that Philoxenos does not explicitly discuss the wording as he does with the previous citations make it difficult to ascertain which form of this verse represents the text of $\mathrm{Ph}$. However, it seems

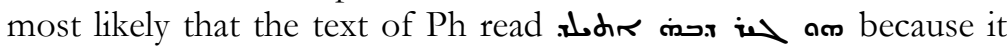
matches the word order of the Greek text and because the text of $\mathrm{H}$ also includes this reading. The variations in the other citations may be explained by accidental reversion to the Peshitta wording (placement of حrit) and inconsistent citation habits with regard to particles/participles (inclusion of in and $-\boldsymbol{\pi}$ ). Unlike the previous two citations discussed above, the precise wording of this verse was

${ }^{49}$ CPJ 227.7-8.

${ }^{50}$ CPJ 41.15-16; CPJ 41.21-22; and (partial) CPJ 236.13-14. It is also worth noting that both word orders appear in two citations of this verse found in the Syriac translation of Cyril of Alexandira's work Apologia Duodecim Capitulorum contra Theodoretum, King, Syriac Versions, 396. The Peshitta word order is also retained in two citations from Tratatus tres (236.38; 268.28-29); however, both of these are partial citations that begin with the phrase in question and this may affect the word order of the citation. 
not as crucial to Philoxenos, so it is not surprising that his citations are varied slightly.

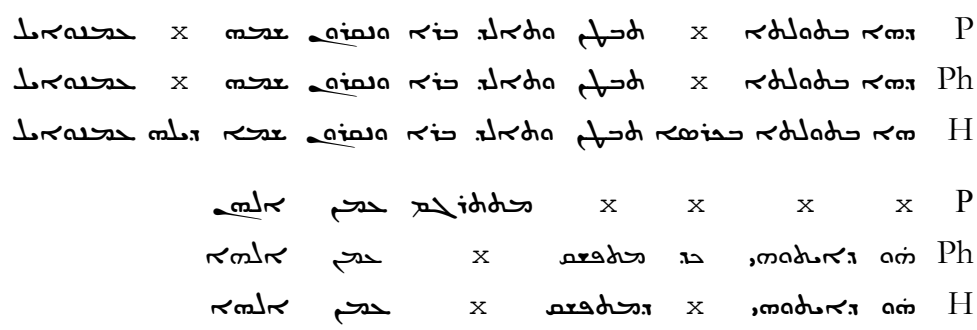

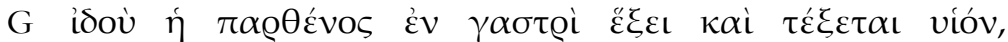

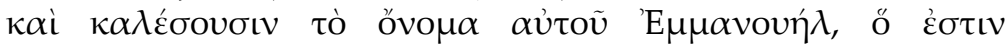

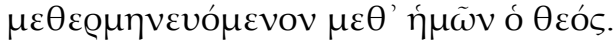

The portion of this citation that is a quote from Isa. 7:14 is identical in the texts of $\mathrm{P}$ and $\mathrm{Ph}$. However, the text immediately following this quotation is different. Philoxenos quotes this verse five times, and three of those five citations include the whole verse..$^{51}$ Moreover, one of the three full citations also includes $1: 22,52$ which is indicated as a citation with the marker $\mathrm{d}$. Based on the length of this citation and the use of the citation marker, we may reasonably conclude that Philoxenos is quoting from a particular text in this verse and not from memory. The text of Ph appears to reflect a word-for-word translation of the Greek phrase

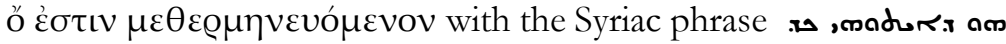
arads. In addition to the change in word order, the text of $\mathrm{Ph}$ also uses ara (Aph._- "to explain, translate") instead of pid ("to interpret, translate") as the translation of the Greek word $\mu \varepsilon \theta \varepsilon Q \mu \eta \nu \varepsilon v o ́ \mu \varepsilon v o v .{ }^{53}$ All three full citations of this verse also

${ }^{51}$ Full: CPJ 46.6-8; 56.15-17; 42.13-14; Partial: CPJ 44.7; CPJ 47. $19-20$.

${ }^{52}$ CPJ 56.14-17.

${ }^{53}$ This translation choice may have been part of a broader translation movement in the fifth and sixth centuries because both forms also exist in the Syriac translation of the works of Cyril of Alexandria ( Scholia de Incaratione Verbi and aradus in Epistle 39; King, Syriac Versions, 398. This reading is also found in the citation of this verse from Tratatus tres (169.4). 
include the temporal preposition $\boldsymbol{\omega}$, likely an attempt to emphasize that this verb is a participle. However, the translator of $\mathrm{H}$ has omitted it, so this appears to be a reading unique to $\mathrm{Ph}$.

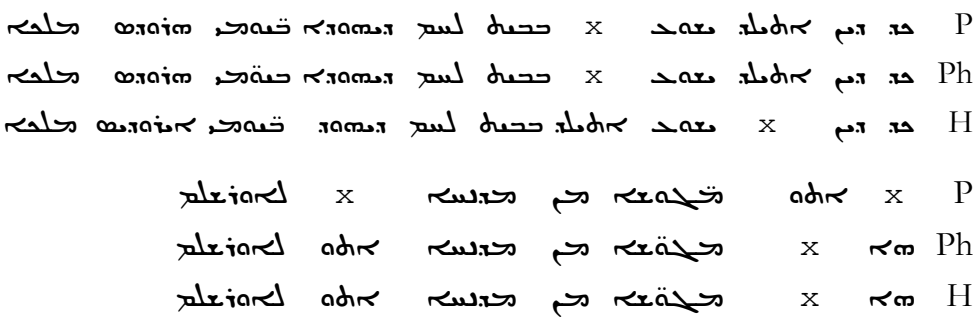

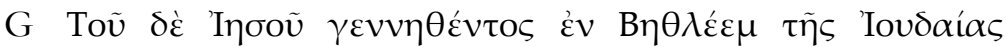

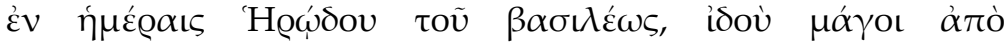

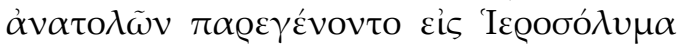

Philoxenos cites this verse fully twice ${ }^{54}$ and partially on two other occasions. ${ }^{55}$ Two of the citations (one full length and one partial) contain the citation marker $>0 .{ }^{56}$ In the full length citation that contains the citation marker positive particle r. However, in the other full length citation,

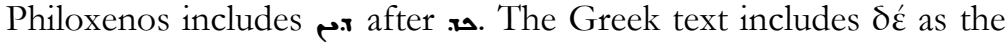
second word in the sentence, so it is likely that the text of $\mathrm{Ph}$ included o.r, but that Philoxenos has simply replaced the particle with $>$ in one citation. It is interesting that the translator of $\mathrm{Ph}$ has not transposed the order of ras a ras the translator of $\mathrm{H}$ has done in order to reflect the Greek word order. However, all three citations of this verse that contain this portion of the text retain the same word order as P. ${ }^{57}$

There is some question about the two revisions in the second half of the verse: the addition of $\sim \mathrm{m}$ and the placement of the verb adr. One full length citation contains the wording equivalent to the text of $\mathrm{P}, 58$ but the other full length citation contains the

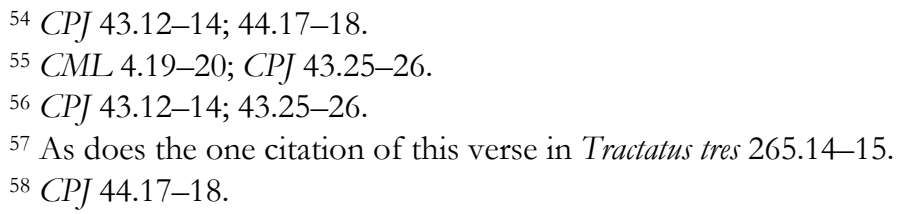


reading presented above. It is more likely that the text of $\mathrm{Ph}$ included the revised version found above for several reasons: 1) the revised citation includes the citation marker 7 and the other one does not; 2) the addition of $\mathrm{rm}$ is an attempt to translate the Greek word ioov and the placement of adr in the revised text reflects the placement of $\pi \alpha \varrho \varepsilon \gamma \varepsilon \dot{v}$ ov $\tau$ in the Greek word order; 3 ) the text of $\mathrm{H}$ also includes both of these revisions; and 4) it is easier to explain the presence of a citation of $\mathrm{P}$ in Philoxenos' writings than it is to explain a variant reading that just so happens to display translation techniques characteristic of the translator of $\mathrm{Ph}$. Philoxenos is not making an explicit point about the wording of this text, so we may assume that the citation that reflects the text of $\mathrm{P}$ is the result of Philoxenos quoting a more familiar wording.

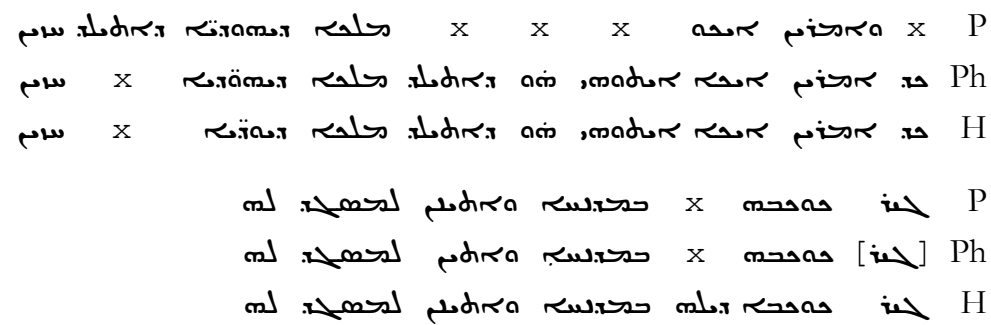

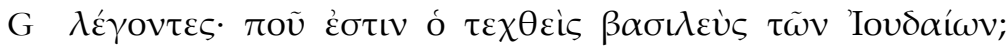

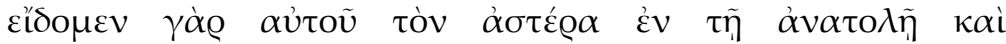

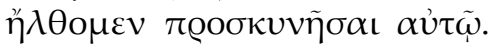

Philoxenos cites this verse twice,,$^{59}$ but the two citations display different readings of the first half of the verse. One citation

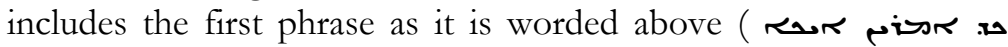

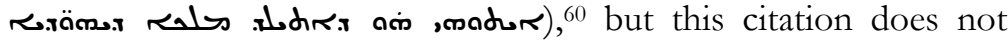
include the rest of the verse. The second citation contains the full verse, but it is identical to the wording of P. ${ }^{61}$ It is concluded here that the text of the shorter citation represents the text of $\mathrm{Ph}$ for the first half of the verse because it agrees with the text of $\mathrm{H}$ and follows the kind of translation technique characteristic of the
${ }^{59}$ CPJ 43.14-15; 44.18-20.
${ }^{60}$ CPJ 43.14-15.
${ }^{61}$ CPJ 44.18-20. 
translator of Ph. Moreover, it is safe to assume that the second half of the verse (beginning with ww) is an accurate reflection of both $\mathrm{P}$ and $\mathrm{Ph}$ because Philoxenos' citation agrees with the virtually identical texts of $\mathrm{P}$ and $\mathrm{H}^{62}$

With regard to the first half of the verse, the text of Ph extends

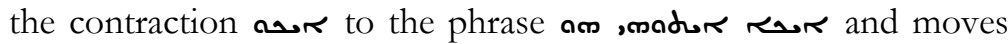
the verb aldr to the position immediately following this phrase in order to provide a word-for-word translation of the Greek wording

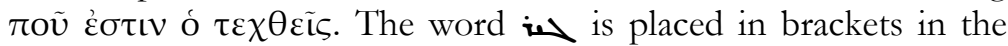
presented text above because while it does not appear in Philoxenos' citation, it is not necessary to conclude that the text of $\mathrm{Ph}$ omitted it. In the text of CPJ, there is a d where the it would stand. It is strange that $>$ appears at this position in the sentence, as it usually appears near the beginning of a citation. However, the replacement of a conjunction with $>$ need not necessarily be considered a definitive omission. As seen in Matt 2:1, Philoxenos sometimes replaces post-positive conjunctions with the citation marker $\mathrm{d}$. This, in addition to the fact that the Greek text includes $\gamma \dot{\alpha} \varrho$ here and both $\mathrm{P}$ and $\mathrm{H}$ contain in allows us to conclude reasonably that the text of Ph likely included is.

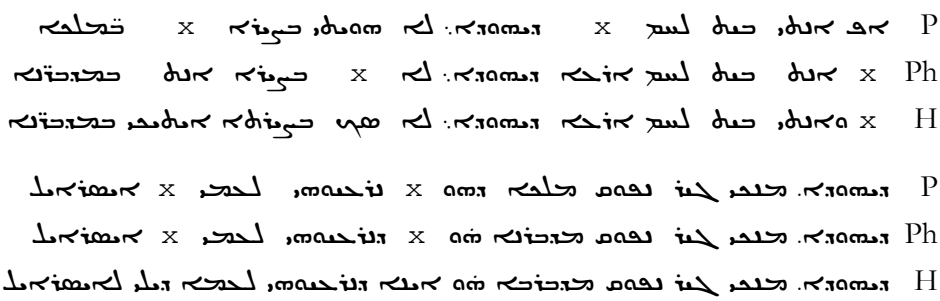

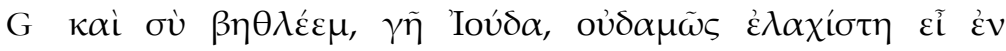

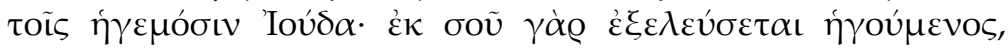

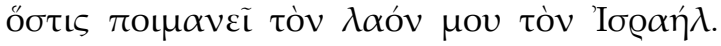

62 The only difference being the addition of $\mathbf{m}$. consistent revision found in $\mathrm{H}$ but not in Ph. Brock also asserts that this is true of the distinctions between the Philoxenian and Harclean recensions of the Syriac Euthalian material. Brock, "The Syriac Euthalian Material," 129. 
Philoxenos quotes this verse only once, ${ }^{63}$ but he expresses an intent to cite by introducing this citation with the phrase ("a statement in the Gospel") and including the citation marker $>$. The texts of $\mathrm{Ph}$ and $\mathrm{H}$ add the word $\sim$ ir, perhaps in an attempt to render more accurately the Greek phrase $\gamma \tilde{\eta}$ 'Iov́ $\delta \alpha$. However, there is a textual variant in the Greek witnesses that could account for the lack of this word in the text of

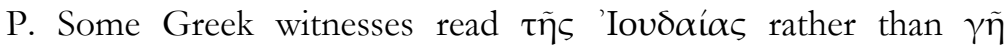
'Iov́d $\alpha .{ }^{64}$ Thus, the most likely explanation for the presence of the word rir in $\mathrm{Ph}$ and $\mathrm{H}$ is that their Vorlagen included the word $\gamma \tilde{\eta}$. The text of $\mathrm{Ph}$ also omits the verb , donor and adds the enclitic second person pronoun dur following $\boldsymbol{R}_{\mathbf{5}}$, perhaps in an attempt to reflect the Greek word order that places the second person singular verb $\varepsilon \tilde{i}$ after $\dot{\varepsilon} \lambda \alpha \chi i ́ \sigma \tau \eta$. Moreover, the translator of $\mathrm{Ph}$ has chosen to translate the Greek word $\eta \gamma \varepsilon \mu \omega \nu$ with the Syriac word ('leader, ruler, governor') rather than saing').

3:15

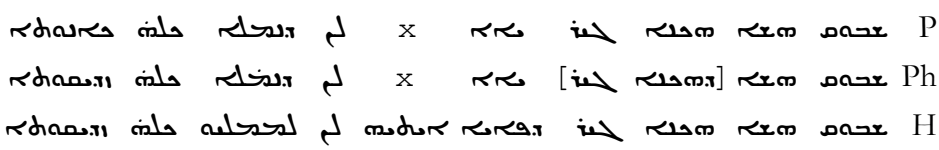

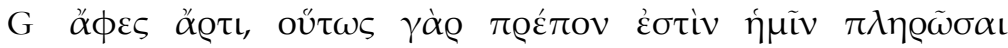

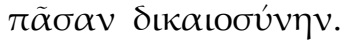

Philoxenos cites this verse twice, though one of them is a partial citation. ${ }^{65}$ The reading in brackets above is uncertain because only one of the two citations contains this part of the verse and it contains two minor variations that are difficult to resolve confidently: the citation of this verse adds the proclitic $-\boldsymbol{x}$ to the word an and omits the conjunction in that immediately follows the texts of $\mathrm{P}$ and $\mathrm{H}$. It is possible that both of these variations are accidental and that neither is actually the reading of $\mathrm{Ph}$. However, it is also possible that the translator of $\mathrm{Ph}$

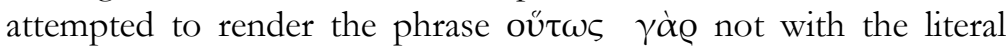

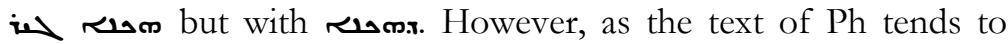

\footnotetext{
${ }^{63}$ CPJ 42.5-8.

${ }^{64}$ The witnesses that attest to this variant are $\mathrm{D} p c$ it sy s.c.p.

${ }^{65}$ CPJ 215.2-3; Partial: CML 22.10-11.
} 
reflect a more word-for-word translation, it is unlikely that the text of $\mathrm{Ph}$ actually omits in. Philoxenos' citation of this verse also substitutes the word ror for the word rasha as a translation

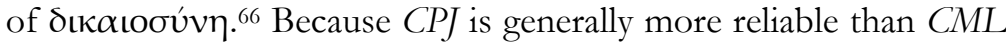
and because $\mathrm{H}$ also includes rhan.m, it is reasonable to conclude that this was the reading of $\mathrm{Ph}$ as well. Moreover, Brock notes that this precise lexical change is characteristic of the citations evident in the Syriac Euthalian materials. ${ }^{67}$

$10: 17$

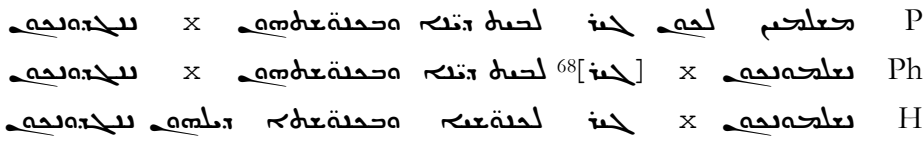

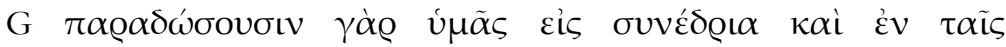

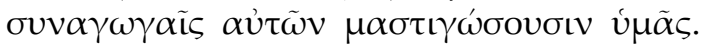

Philoxenos does not include the first phrase of this verse in his only citation, ${ }^{69}$ but he does introduce the citation with the marker J. Although the translator of $\mathrm{H}$ revises the text of $\mathrm{P}$ in a number of places, there is only one revision in the text of $\mathrm{Ph}$. The translator of $\mathrm{Ph}$ changed the form of the verb strarticiple) to صلsird person imperfect plural). It is likely that the translator made this change to reflect the future tense of the Greek verb $\pi \alpha \varrho \alpha \delta \omega \sigma o v \sigma \iota v$. However, it is not clear why the translator added the second person plural pronoun (functioning as the direct object) to the end of the verb. Generally, the translators of $\mathrm{Ph}$ and $\mathrm{H}$ attempt to match the Greek word order, but in this case, the word order of the text of $\mathrm{P}$ better resembles the Greek $\pi \alpha \varrho \alpha \delta \omega \sigma o v \sigma \iota v \gamma \grave{\alpha} \varrho \dot{v} \mu \tilde{\alpha} \varsigma$. Once again, we should not regard the omission of $i$ as a variant of the text of $\mathrm{Ph}$ because Philoxenos has placed the citation marker $>$ in the position of in in the

${ }^{66}$ However, the partial citation of this verse in CML reads rodour.

${ }^{67}$ Brock, "The Syriac Euthalian Material," 128. Though, as King points out, the mid seventh-century Syriac translation of Severus' $A d$ Nephalium reverts to the usage of Rdour; King, Syriac Versions, 399.

68 The brackets indicate that the word is not in the citation taken from Philoxenos' writings but should be considered part of the text of $\mathrm{Ph}$.

${ }^{69}$ CPJ 127.23-24. 
citation, and we have already seen that this is not indicative of an omission in $\mathrm{Ph}$.

$10: 21$

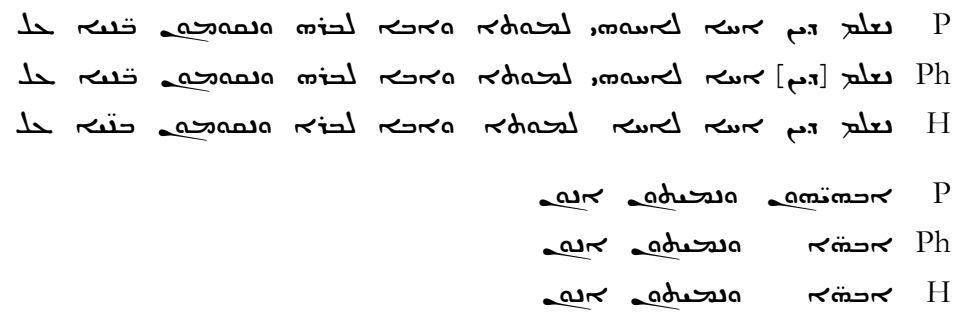

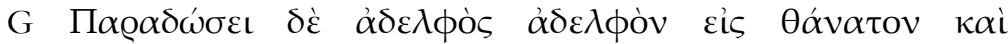

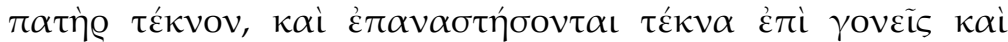

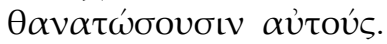

The text of this verse as cited by Philoxenos ${ }^{70}$ omits the conjunction ax, though we should not consider this to be an actual omission from the text of $\mathrm{Ph}$. This is most likely an accidental omission, though it could be a stylistic choice for the context of the citation. The primary revision found in the text of $\mathrm{Ph}$ is the omission of the third person plural possessive ending from

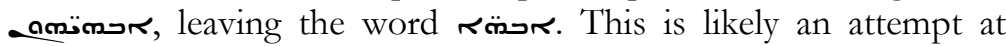
word-for-word translation because there is no possessive pronoun here in the Greek text.

11:27

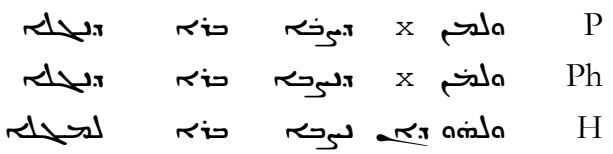

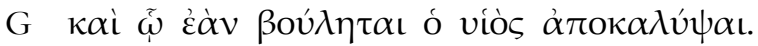

Although this citation is rather short, ${ }^{71}$ there is good reason to conclude that it reflects the wording of Ph. The variant in question here is the change of the verb (perfect participle) to s s (imperfect) in order to reflect the

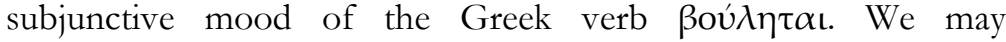

\footnotetext{
${ }^{70}$ CPJ 127.24-25.

${ }^{71}$ CPJ 180.26-27.
} 
reasonably conclude that this reading represents the text of $\mathrm{Ph}$ because Philoxenos includes the citation marker ot, other citations from $\mathrm{Ph}$ demonstrate an attempt to translate the tense of Greek verbs more accurately, ${ }^{72}$ this reading is attested in one of Philoxenos' other later works, ${ }^{73}$ and the variation is also found in $\mathrm{H}$.

16:18

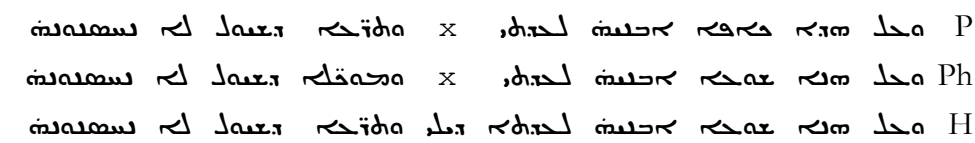

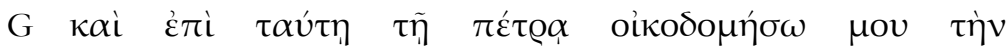

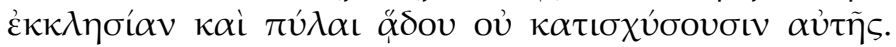

In Philoxenos' citation of this verse ${ }^{74}$ two out of three variations from the text of $\mathrm{P}$ agree with the text of $\mathrm{H}$. The later translators have exchanged ar for and altered the demonstrative pronoun from the feminine rim to the masculine this change. This revision appears to be a revision aimed at a more "accurate" translation of $\pi \dot{\tau} \tau \varrho \alpha$. P. Hill asserts that ro "unambiguously means 'rock,' whereas ara may mean 'stone' or 'rock'," as well as other elliptical meanings such as "column," "stone vessel," and "idol."”

The most interesting variation in the text of $\mathrm{Ph}$ in this passage, however, is the change from ("bars [of iron]"). This variant is interesting because it seems that Philoxenos preserves a reading found in the Diatessaron that is not found in either $\mathrm{P}$ or $\mathrm{H}$. Brock ${ }^{76}$ and Murray ${ }^{77}$ argue that Tatian included the word sased on an early Christian interpretation of Psalm 107:16 regarding the descent of Christ to hell after his death. In this interpretation, the sare the bars of Sheol that Christ has

${ }^{72}$ See discussion of 3:12 above.

${ }^{73}$ LMS 70.3. This citation also adds an as a translation of the Greek article ó.

${ }^{74}$ CPJ 128.15-16.

${ }^{75}$ Hill, "Matthew 16:18 in the Philoxenian Version," 7.

${ }^{76}$ Brock, "Some Aspects of Greek Words in Syriac," 95-98.

77 R. Murray, "The Rock and the House on the Rock," OCP 30 (1964): 341. 
broken down in order to defeat death and harrow Hell. ${ }^{78}$ The

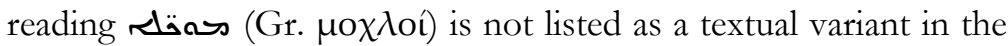
apparatus of $\mathrm{NA}^{27}$ or Pusey and Gwilliam's critical Peshitta text, so it is unlikely that the translator of $\mathrm{Ph}$ simply kept this reading from the base P text or translated it from the Greek Vorlage. Moreover, it is also worth noting that Philoxenos also uses so in his citation of this verse in $L M S .{ }^{79}$

There are several possible explanations for the occurrence of this reading in the text of $\mathrm{Ph}$ : perhaps Philoxenos had access to a copy of the Diatessaron; perhaps the variant reading existed in the Peshitta text of Philoxenos (and Polycarp); or perhaps Philoxenos knew of the interpretive tradition of Psalm 107 and agreed with it to the extent that he was willing to include the reading in his version. Or, perhaps it is a combination of these factors. Hill concludes that it is possible that the Greek Vorlage of $\mathrm{Ph}$ included

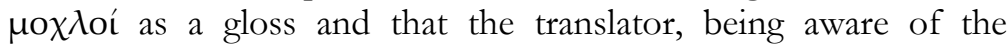
interpretive tradition, chose to include this reading against the text of P. ${ }^{80}$ Given the fact that the text of $\mathrm{Ph}$ generally represents an attempt to translate the Greek text more literally, it seems that this is the best explanation for the existence of the reading in $\mathrm{Ph}$. Thus, the fact that Philoxenos includes to the theory of Murray and Brock that this was in fact a strong interpretive tradition.

${ }^{78}$ Brock, "Some Aspects of Greek Words in Syriac," 96. However, P. Hill argues that sor may not have been the original reading of the Diatessaron but rather a gloss by Ephrem based on the interpretive tradition mentioned above. Hill, "Matthew 16:18," 8.

${ }^{79} L M S$ 77.23-24. The text of this citation is identical to the text presented above except that it uses the extended possessive clause ז.

${ }^{80}$ Hill, "Matthew 16:18," 10. 
19:28

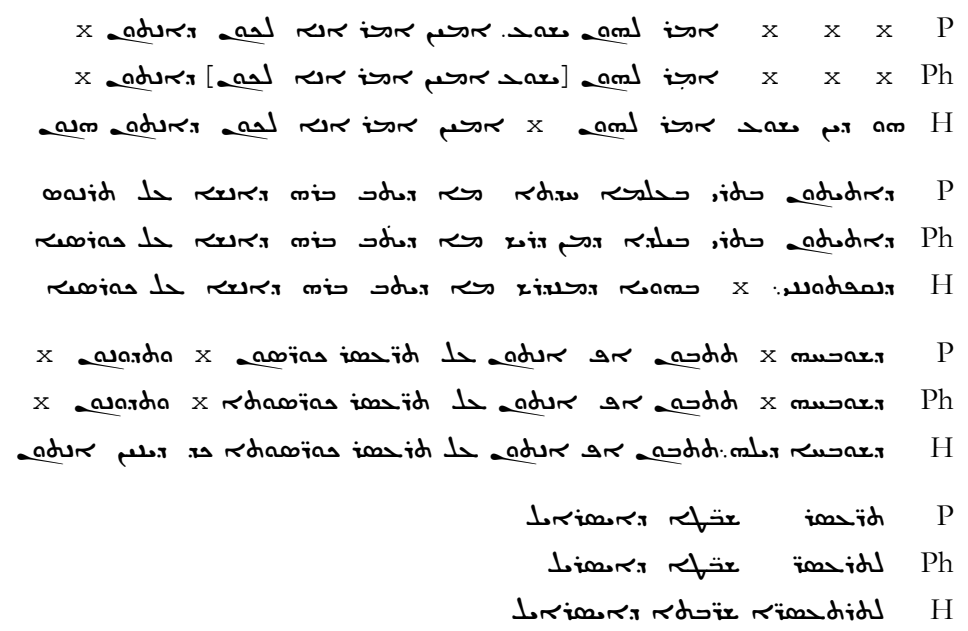

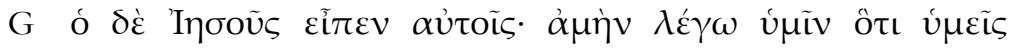

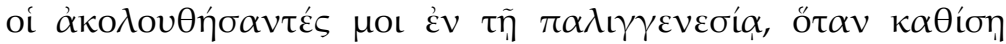

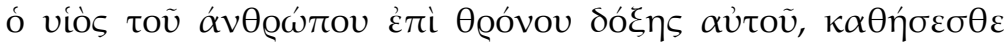

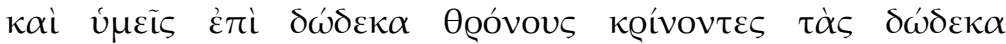

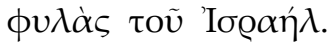

Philoxenos introduces this citation ${ }^{81}$ with the phrase written [that]"). The brackets above indicate that this citation does

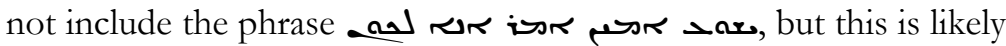
the result of an adaptation based on citing context and it should not be concluded that this phrase is absent from the text of $\mathrm{Ph}$. The various attempts to translate the Greek word $\pi \alpha \lambda$ เ $\gamma \varepsilon \varepsilon v \varepsilon \sigma i \alpha$ ("state of being renewed; experience of a complete change of life, rebirth") 82 result in one of the rare occasions in which none of the three witnesses agree with one another. The text of $\mathrm{P}$ renders the word "the new age" (ححلs), while the translator of $\mathrm{Ph}$

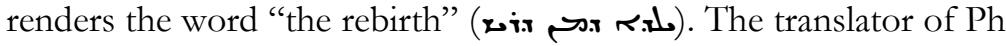
exchanges rdiw for wix $\boldsymbol{r}$, which can be translated idiomatically as "again." 83 This appears to be an attempt by the translator of $\mathrm{Ph}$ to translate the Greek compound word by translating the two
${ }^{81}$ CPJ 210.4-8.
82 BDAG, 752.
${ }^{83}$ Smith, CSD, 540. 
words of the compound word separately. While this technique

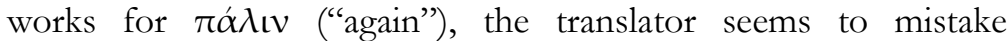
$\gamma \varepsilon v \varepsilon \sigma i ́ \alpha$ for a derivative of $\gamma \varepsilon v \nu \alpha ́ \omega$ ("to beget, give birth") rather

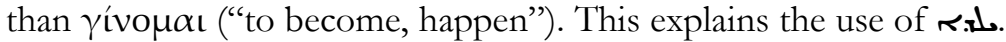
The translator of $\mathrm{H}$, on the other hand, retains the phrase wis but translates $\gamma \varepsilon v \varepsilon \sigma i \alpha$ with the Syriac word ram from ram ("to happen, become"). The differences between the readings of this variant actually provide support for the representation of the text of $\mathrm{Ph}$ - it shows that translators struggled with how to translate Greek words for which there was no Syriac equivalent. The next variant appears to be an attempt to correct an inconsistency in the translation of $\mathrm{P}$ within this verse. The Greek word Ooóvos appears twice in this verse, and the text of $\mathrm{P}$ offers two translations: transliterated from the Greek Opóvos, and حمiّi) (sg: which also means "throne." The texts of $\mathrm{Ph}$ and $\mathrm{H}$, however, replace osid with sooris so that the translation is consistent.

\subsection{Philoxenian Gospel of Luke}

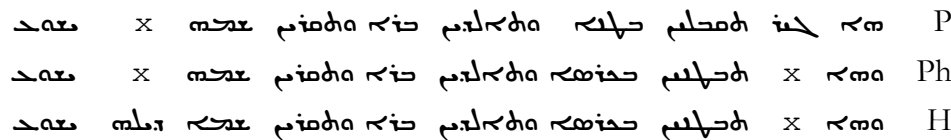

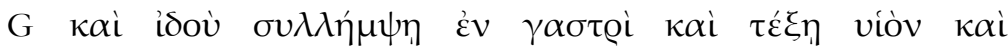

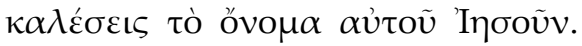

Philoxenos quotes this verse three times, ${ }^{84}$ and two of the citations include the text presented above. The text of Ph omits in most likely because $\gamma \alpha \dot{Q} \mathrm{Q}$ does not appear in the Greek text. ${ }^{85}$ The text of $\mathrm{Ph}$ includes a more literal rendering of the Greek phrase

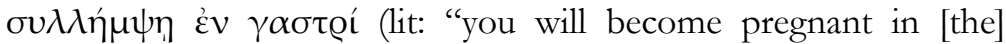
belly") by changing the phrase "if (lit: "you will receive pregnancy") to roin حس (lit: "you will become pregnant in the belly"). One of the three citations ${ }^{86}$ of this verse from

${ }^{84}$ CPJ 45.9-10; 45.11-12; 47.15-17.

85 in does appear in a citation of this verse in $L M S$ (58.22), but it appears after, not before,

${ }^{86}$ CPJ 47.15-17: ה. 


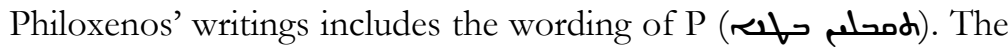
rest of the text of this citation, however, has clearly been adapted to the author's style, as it is conflated with a portion of $\mathrm{Lk} 1: 35$; so this citation should not be considered part of the text of $\mathrm{Ph}$. However, the citation that includes the wording of $\mathrm{P}$ is significant because Philoxenos includes the introductory formula אתبن ("But Luke says"). Thus, in his three quotations of this verse, Philoxenos provides an introductory formula only for the quotation that agrees with $\mathrm{P}$. However, despite the lack of introductory formula, it is reasonable to conclude that the text of $\mathrm{Ph}$ contains the reading roin shecause this wording appears twice in full citations in CPJ, it appears once in an extended citation in $L M S,{ }^{87}$ and it appears in $\mathrm{H} .{ }^{88}$

$1: 35$

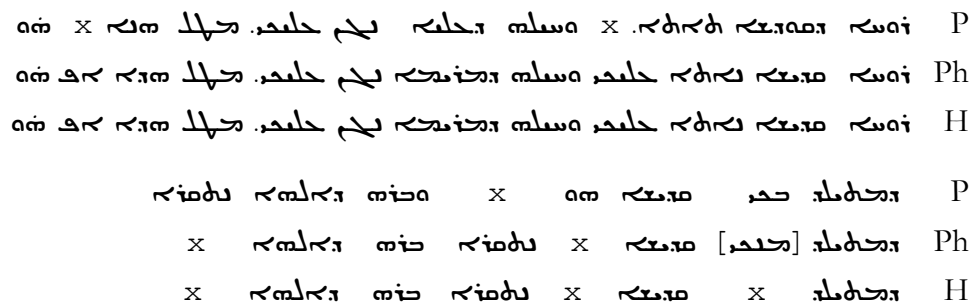

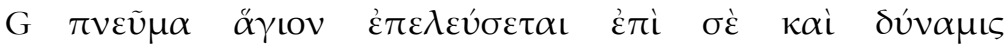

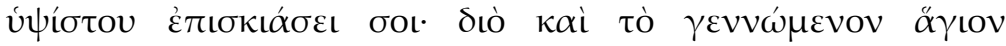
$\kappa \lambda \eta \theta \eta ́ \sigma \varepsilon \tau \alpha \iota ~ v i o ̀ s ~ \theta \varepsilon o \tilde{~}$

The $\mathrm{Ph}$ text of $\mathrm{Lk} 1: 35$ is particularly difficult to determine because Philoxenos cites this verse several times in conflicting forms, even within the same work. 89 There are five citations of this verse in Philoxenos' exegetical writings: two full ${ }^{90}$ and three

${ }^{87}$ LMS 58.22.

88 The Syriac translation of Cyril of Alexandria's Epistle 39 also indicates the change in verb to or rمin; King, Syriac Versions, 422.

89 CPJ, LMS, and Tractatus tres all contain multiple citations of this verse and the citations are varied in all three works.

${ }^{90}$ CPJ 211.26-28; CPJ 41.2-4. 
partial, ${ }^{91}$ and there are two full citations of this verse in $L M S^{92}$ and Tract. tres. ${ }^{93}$ In two of the citations, Philoxenos demonstrates an intent to cite with the citation marker $7 .{ }^{94}$ Moreover, all of the full citations are nearly identical, though their minor discrepancies make establishing portions of this verse quite difficult. All of the citations that contains the verb demonstrate a revision in the gender of the verb rdir ("to come") from feminine to masculine in order to portray the Holy Spirit as grammatically masculine rather than feminine..$^{95}$ The text of $\mathrm{Ph}$ also adds the phrase حلe ("upon you") to represent the Greek phrase غं $\pi \dot{\imath} \sigma \dot{\varepsilon}$; this too is attested in all of Philoxenos' full citations of the verse. There is

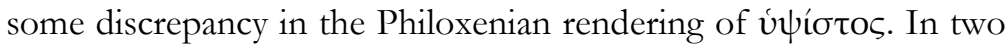
citations ${ }^{96}$ Philoxenos retains حلrom $\mathrm{P}$ and in the other three he uses sis. However, one of the citations that uses حلs is found in CML and the other is the partial citation that appears to be simply an allusion. ${ }^{97}$ All of the full citations of this verse use

${ }^{91}$ CPJ 41.34-24; CPJ 196.19; CML 54.12-13, though CPJ 196.19 is clearly an allusion.

${ }^{92}$ LMS 39.16-17, 60.9-11.

93 Tract. tres 236.29-237.1; 95.2-5.

${ }^{94}$ CPJ 211.26-28; CML 54.12-13 (This citation comes from MS A in CML).

${ }^{95}$ In early Syriac writings, the Holy Spirit is generally considered to be feminine because grammatically the word ruai is feminine. For more on the shift within the Syriac language from a feminine to a masculine Holy Spirit, see S. Brock, "CCome, Compassionate Mother..., Come Holy Spirit': A Forgotten Aspect of Early Eastern Christian Imagery," Aram 3 (Oxford, 1991), 249-257; reprinted in Brock, Fire From Heaven. Moreover, Zuntz found this revised translation in Tractatus Tres and noted its significance with regard to translation technique, The Ancestry of the Harklean Version, 43.

${ }^{96}$ CPJ 196.19; 47.15-17. The latter of these two citations is conflated

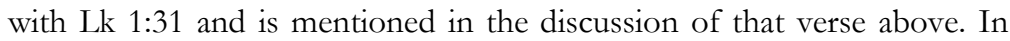
both 1:31 and 1:35, this citation retains readings from the text of $\mathrm{P}$. However, Philoxenos has clearly adapted the wording to fit his context, so it is difficult to argue that this citation represents the text of $\mathrm{P}$, particularly when there are longer citations that do not agree with the text of $\mathrm{P}$.

${ }^{97}$ King notes that when Philoxenos alludes to this verse, his wording tends to revert to that of $\mathrm{P}$ rather than citing precisely the text of $\mathrm{Ph}$. King, Syriac Versions, 424. 
sois, and this is also found in the text of $\mathrm{H}$. Thus, it is reasonable to conclude that

The next three variants are extremely difficult to deal with because Philoxenos quotes this verse twice in CPJ and twice in $L M S$ and both works contain conflicting forms of the text with regard to the following variants. The first is the question of the addition of 9 r in order to reflect the Greek conjunction kat. The text of $\mathrm{H}$ includes the addition, and two of Philoxenos' citations do as well,98 but two of the full citations lack this word. One of Philoxenos' full length citations of this verse omits ar. Given the fact that Philoxenos includes $9 r$ twice and that it exists in the text of $\mathrm{H}$, it seems that the best explanation is that it was part of the text of $\mathrm{Ph}$ and that Philoxenos simply forgot it in two other citations: It is easier to explain its omission in his citations than its inclusion.

Next, it is difficult to determine which form of the phrase r.m/ $/$ wo is the original text of $\mathrm{Ph}$. Two of the four full citations of this verse use rm and the other two use rim, and once again, both readings appear in CPJ and in $L M S{ }^{99}$ It is tempting to assert that the reading of $\mathrm{Ph}$ is r.ro because of its prevalence in other translations of the time 100 and because it appears also in $\mathrm{H}$. However, because the citations of Philoxenos are split and all four citations are full length citations, it is not easy to dismiss easily. ${ }^{101}$ Moreover, we cannot rely on the argument that one is a "better" translation than the other. However, it is easier to explain an accidental reversion to the Peshitta reading than it is to suggest an accidental revision to a reading that also happens to occur in other versions. Thus, it seems best to conclude that the text of $\mathrm{Ph}$ read rim ths.

There is also some question as to whether or not the text of $\mathrm{Ph}$ agrees with $\mathrm{P}$ or $\mathrm{H}$ with regard to the retention of the phrase حص, Two of Philoxenos' citations of this verse (one from CPJ and one

98 This citation in LMS (60.9-11) also includes a $-\mathrm{a}$ attached to 9 r.

${ }^{99}$ Both citations of this verse in Tractatus tres use rm.

${ }^{100}$ King notes that ram is found universally in the Syriac translations of the works of Cyril and calls Philoxenos' use of this wording "archaic." King, Syriac Versions, 424.

101 ros also appears in both citations of this verse in Tract. tres. 
from LMS) omit حص, ${ }^{102}$ but one retains it. ${ }^{103}$ Moreover, to make the matter more complicated, Philoxenos' fourth full citation of this verse includes 1 . $^{104}$ Of the two citations of this verse in Tractatus tres, one retains כת and one includes דתמ. The discrepancy could be the result of a textual variant in the Greek manuscripts used in translation: Several Greek witnesses attest to the inclusion of the phrase $\dot{\varepsilon} \kappa$ oov following the verb $\gamma \varepsilon v \nu \omega \mu \varepsilon v o v$ (ad). ${ }^{105}$ Although the preposition $\rightarrow$ is not the common translation of $\dot{\varepsilon} \kappa$, this textual variant can explain the use of حص כ in the Syriac text of P. However, this does not necessarily explain why Philoxenos presents three different forms of this text. To complicate matters further, תבתו is also a variant reading in the Peshitta tradition. ${ }^{106}$ It could be argued that the reading is the text of $\mathrm{Ph}$ because it is a better translation of the Greek phrase, but this does not explain the use of בص in multiple citations. Based on the text critical axiom that the reading that best explains the others is the best reading, it seems that the best explanation is this: the Greek Vorlage used in making $\mathrm{Ph}$ included the Greek phrase غ̇k бoṽ, which the translator (correctly) revised from P's כת to (107 Philoxenos' citation is an accidental reversion to the reading of $\mathrm{P}$; and the two omissions of the phrase are accidental omissions.

The final revision of this verse in the text of $\mathrm{Ph}$ is far more easy to establish with confidence than the previous three. The text of $\mathrm{Ph}$ demonstrates a revised word order of the final phrase by placing the verb before the direct object. This alteration is likely an attempt to reproduce the Greek word order $\kappa \lambda \eta \theta \eta ́ \sigma \varepsilon \tau \alpha \iota$ viós

102 CPJ 211.26-28; LMS 60.9-11.

103 CPJ 41.2-4.

${ }^{104}$ LMS 39.16-17.

105 The witnesses that attest to this reading are $C^{*} \Theta f^{1} 33 p c$ a c e vgcl Ir $^{\text {lat }}$ Tert Ad Epiph.

106 Pusey and Gwilliam, Tetraenangelium Sanctum, 322.

107 Though, it is possible that the version of $\mathrm{P}$ with which the translator was familiar used דصט. 
$\theta \varepsilon o \tilde{v}$. All of the full citations of this verse in Philoxenos' writings and the text of $\mathrm{H}$ also include this revised word order. ${ }^{108}$

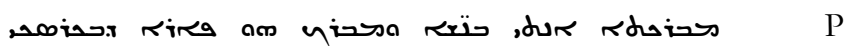

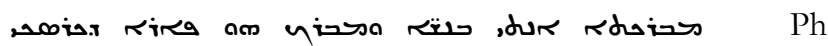

S

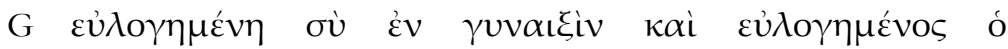

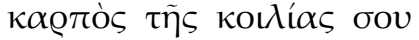

Philoxenos introduces this citation and expresses an intent to cite with the phrase disrs s ("It is written that she [Elizabeth] said..."). ${ }^{109}$ The variation in question is the omission of the

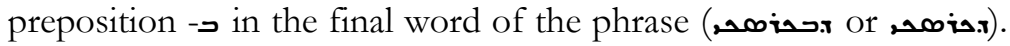
The text of $\mathrm{P}$ is translated "Blessed is the fruit that is in your womb," with the initial - functioning as a relative pronoun and the preposition 2 specifying the location of the fruit. However, there is no preposition in the Greek text to represent - because it uses

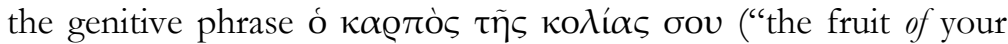
womb"). By removing the preposition $ב-$, the text of $\mathrm{Ph}$ allows the initial $-\boldsymbol{x}$ to function as a genitive and renders the Greek more accurately as

$1: 43$

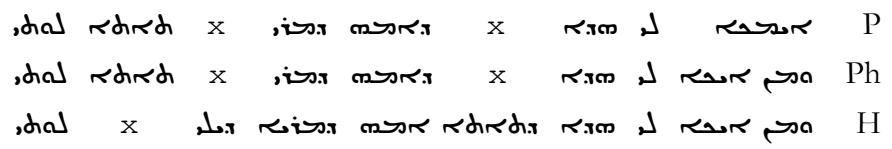

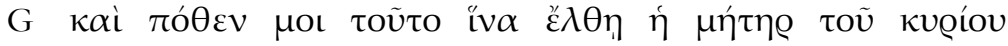

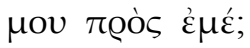

The citation of this verse ${ }^{110}$ contains a revised translation of the Greek word $\pi$ ó $\theta \varepsilon v$ and replaced ("where? whence?") with

108 Of the two citations of this verse in the Syriac translation of Cyril of Alexandria's works, one demonstrates the word order of $\mathrm{P}$ and the other that of $\mathrm{Ph} / \mathrm{H}$. King, Syriac Versions, 423-424.

${ }^{109}$ CPJ 209.7-8.

${ }^{110}$ CPJ 209.8-9. 
the virtually equivalent phrase ra ("whence?").111 While $\pi o ́ \theta \varepsilon v$ does mean "where?" or "whence?", it also carries the tertiary meaning "why?", and it is this meaning that is used in Luke 1:43. Thus, neither $\mathrm{Ph}$ nor $\mathrm{P}$ correctly interprets the nuance of the question.

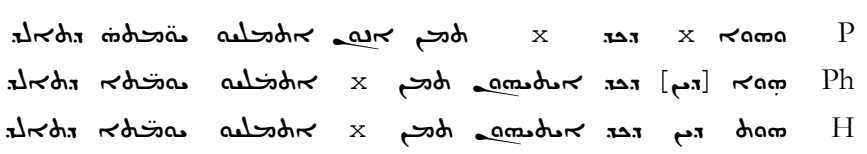

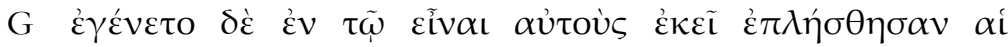

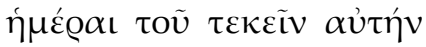

In his citation of this verse, ${ }^{112}$ Philoxenos provides intent to cite with the citation marker $\mathrm{d}$. The text of this verse in CPJ does not include the conjunction ax, but the citation marker stands in the text where this conjunction would stand, and we have already seen evidence that Philoxenos often replaces post-positive conjunctions with the citation marker. Thus, while it is not certain that the text of $\mathrm{Ph}$ originally included $\mathrm{x}$, it is likely that the translator of $\mathrm{Ph}$, like the translator of $\mathrm{H}$, added this conjunction to reflect the Greek $\delta \dot{\varepsilon}$. The translator of $\mathrm{Ph}$ has also added the verbal phrase amsoror as

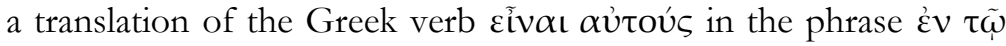

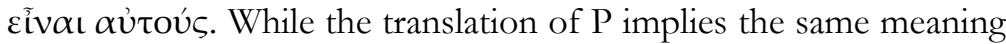
as the Greek phrase, we see the translators of $\mathrm{Ph}$ and $\mathrm{H}$ attempting a "literal" translation of each Greek word.

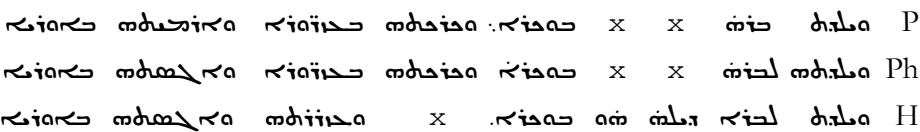

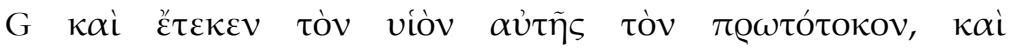

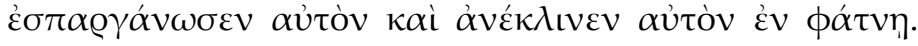

The citation of this verse ${ }^{113}$ includes the addition of the third person direct object pronoun m- to the end of the verb has as well

\footnotetext{
111 Smith, CSD, 13.

112 CPJ 209.4-5.

113 CPJ 209.5-6.
} 
as the direct object marker -$\lrcorner$ to the word $r$. though not certain, that Philoxenos' text of the Peshitta retained this reading because the OS manuscript $S$ also read mondon, though Pusey and Gwilliam do not list this variant in their critical edition of the Peshitta. However, the use of this direct object marker is an orthographic variation that does not change the meaning of the phrase at all, so its inclusion in the text of $\mathrm{Ph}$ has no bearing on the meaning of the sentence, but there is no reason to conclude that it was not part of the text of $\mathrm{Ph}$. Moreover, the text of $\mathrm{H}$ also retains the direct object marker. Thus, we may tentatively conclude that this wording is the text of $\mathrm{Ph}$. The text of $\mathrm{Ph}$ also includes mhan $\checkmark$, an Aphel form of a ("to make recline, to seat"), as the

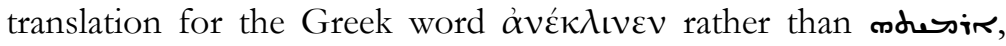
from ri ("to put, place") as found in P.114 The translator of H also retains this reading, so this revision was likely an attempt at a better translation.

2:14

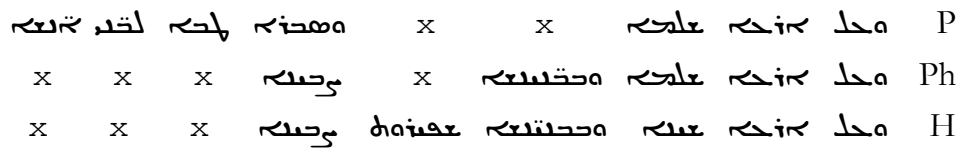

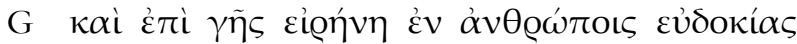

The revision found in this citation ${ }^{115}$ of $\mathrm{Ph}$ from the text of $\mathrm{P}$ may be the result of textual variation in the Vorlagen of these

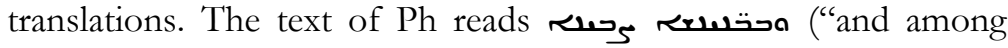
people [good] will") while the text of P reads لتصد تحتv ("and good will to/for people"). The text of Ph appears to be an attempt to accurately translate the word order of the Greek

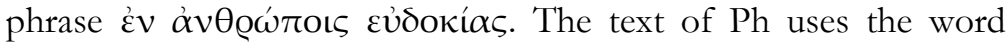
Sבת ("will, desire, delight") as an equivalent for the Greek

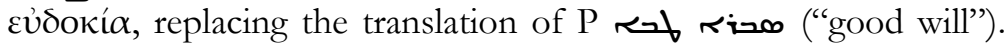
The translator of $\mathrm{H}$ also uses the word ${ }_{5}$ but adds the modifier doinar (from inar "fair, good, lovely") as a translation of the Greek prefix $\varepsilon \hat{v}$-. It is odd that Philoxenos' citation does not

114 One citation of this verse from Tract. tres (265.22-23) retains the reading of $\mathrm{P}$ here, but is otherwise identical to the text given above.

115 CPJ 57.10-11. 
include a translation of this prefix. Concerning this variation, Bas ter Haar Romeny argues that while it could be assumed that Philoxenos is simply careless here, the differences in the translations "demonstrate the independence of the translators."116 Thus, while it is possible that Philoxenos was careless in this citation and accidentally omitted a word, it is also possible that the text of $\mathrm{Ph}$ did not include a separate word to translate the prefix $\varepsilon \dot{v}$-.

$2: 34$

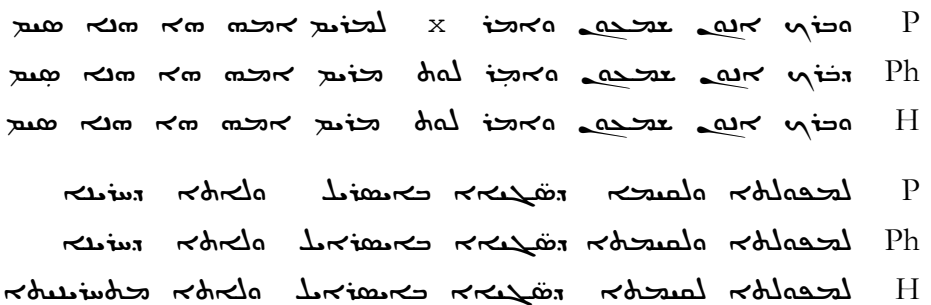

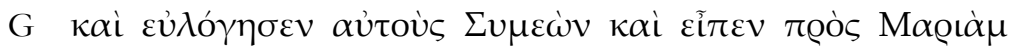

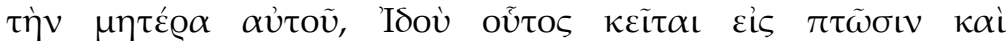

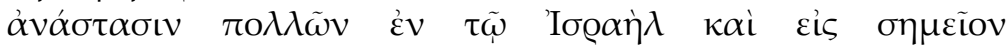
$\dot{\alpha} v \tau \iota \lambda \varepsilon \gamma o ́ \mu \varepsilon v o v$

Reconstructing the text of this verse from Philoxenos' writings is difficult because he quotes it three times, but one citation is only the first phrase, ${ }^{117}$ and the other two citations contain the rest of the verse (but not the first part). This is complicated further by the fact that the latter two citations differ from one another in a few regards. ${ }^{118}$ However, despite the fact that the citation from CML includes the citation marker 7 , the text has at least partially been adapted in the context (see previous footnote for the texts). The first phrase of the sentence includes one revised reading from the text of P: the extension of the phrase orisd ("to Mary") to the longer, but equivalent in meaning, phrase

\footnotetext{
116 Romeny, “A Philoxenian-Harclean Tradition?,” 67.

117 CPJ 209.12-13.

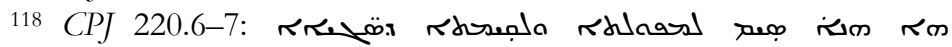

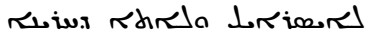

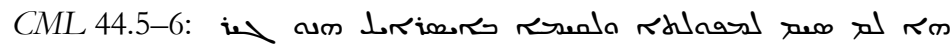

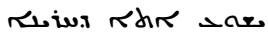


is likely an attempt by the translator of $\mathrm{Ph}$ to account for the presence of the Greek preposition reós. One of the two citations that includes the remainder of the verse includes the citation marker $\mathbf{d}$ in the place of $\boldsymbol{\sigma r}$. However, we should not conclude that the text of $\mathrm{Ph}$ omits $\mathrm{m}$ because Philoxenos frequently replaces inconsequential words with this citation marker. ${ }^{119}$

There is some question about whether or not the text of $\mathrm{Ph}$ should read ملمدs (with P) or Rasth H). In one citation, the text of this verse reads renda, and Philoxenos includes the citation marker in this citation. ${ }^{120}$ However, this text is found in $C M L$ and the fragment that contains this text is found only in two late MSS. ${ }^{121}$ Because of the late date and scribal transmission of this text, it is more likely to have been altered (intentionally or not) to the received spelling of the Peshitta. Both citations from Philoxenos include the initial $-a$, so it seems clear that it was included in the text of $\mathrm{Ph}$. Thus, we may conclude that the text of $\mathrm{Ph}$ read rdreado.

There is, however, a variant reading in the text of $C P J$ that we do not ascribe to the text of $\mathrm{Ph}$. The citation from CPJ reads

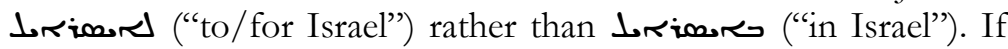
the text of $\mathrm{Ph}$ did include the former reading, then both the translator of $\mathrm{H}$ and a later scribe responsible for the text of the fragment in CML changed the -$\lrcorner$ back to a $\mathbf{a}$. While this is certainly a possible explanation, it seems unlikely that the translator of $\mathrm{Ph}$ who generally corrects prepositions based on the Greek text would have translated the Greek phrase $\dot{\varepsilon} \nu \tau \tilde{\omega}$ 'IбQ $\alpha \eta \dot{\lambda} \lambda$ as Lrion. It is also possible that the scribe responsible for the MS of CPJ accidentally included -$\lrcorner$ because the two previous nouns

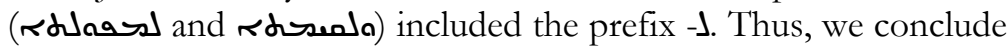
that the text of Ph originally read 1 .

119 Though it is worth noting that in most cases Philoxenos omits a conjunction and not a pronoun.

${ }^{120}$ CML 44.5-6.

121 MSS D and E are listed as 13th century mss. See Watt, 10, for a description. 


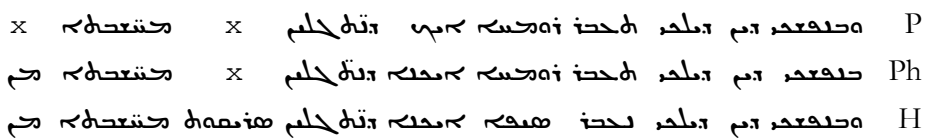

P

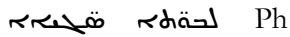

H

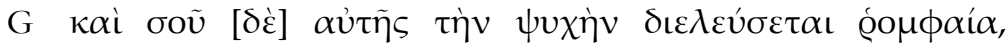

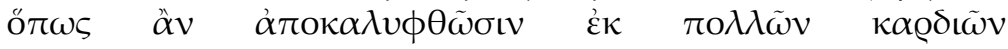

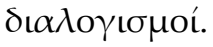

The citation presented above is part of a longer quotation encompassing most of 2:34 and all of 2:35.122 The text of $\mathrm{Ph}$ is nearly identical to the text of $\mathrm{P}$, except for two minor revisions that are also included in the text of $\mathrm{H}$. The text of $\mathrm{Ph}$ includes the contraction restead of the shorter ure. There is no apparent reason for this change because there is no change in the meaning, and there is no apparent Greek word which the translator of $\mathrm{Ph}$ is attempting to replicate. The other revision from the text of $P$ in this verse is the addition of the preposition 3 . The text of the OS S contains this word, but the text of $\mathrm{P}$ does not. However, this could also be the result of a textual variant in the Vorlage of the text of P. Several manuscripts omit the preposition $\dot{\varepsilon} \kappa,{ }^{123}$ so it is possible that the Greek text behind the text of $\mathrm{P}$ also omitted it and, likewise, that the Greek texts behind the translations of $\mathrm{Ph}$ and $\mathrm{H}$ included it. However, it is also possible that the Greek text behind the translation of $\mathrm{P}$ did include $\dot{\varepsilon} \kappa$ and that the translator(s) of $\mathrm{P}$ utilized the genitive action of the prefix $-\boldsymbol{x}$ to convey the same meaning. Considering the fact that both $\mathrm{Ph}$ and $\mathrm{H}$ omit this prefix, this is the most likely explanation. Thus, $\mathrm{sy}^{\mathrm{P}}$ should be removed from the critical apparatus of $\mathrm{NA}^{27}$ as a witness to the absence of $\dot{\varepsilon} \kappa$.

${ }^{122}$ CPJ 220.6-9. See discussion of 2:34 above.

123 The witnesses that omit $\dot{\varepsilon} \kappa$ (other than P) are: D sa bo ${ }^{\mathrm{mss}}$. 


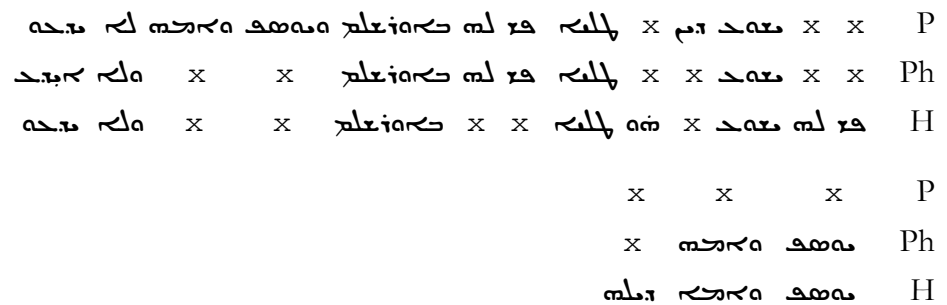

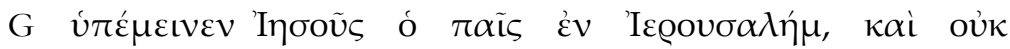

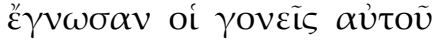

The citation of this verse from $\mathrm{Ph}^{124}$ and the text of $\mathrm{H}$ both omit the conjunction ar, presumably because there is no conjunction here in the Greek text. The conclusion that this omission is not accidental or simply a result of Philoxenos' stylistic concerns is strengthened by evidence later in the phrase that the translations of $\mathrm{Ph}$ and $\mathrm{H}$ reflect the Greek word order. Each of the later translations transposes the phrase m m

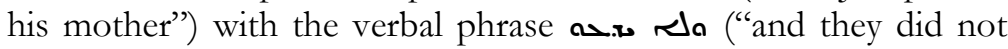
know") in order to reflect the Greek word order. However, there is some question as to what the original Greek text of this phrase actually read. The critical text of $\mathrm{NA}^{27}$ reads oủk $\varepsilon$ k $\gamma \omega \omega \sigma \alpha \nu$ oi

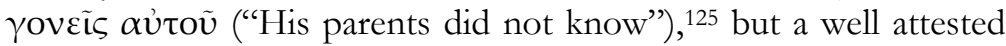

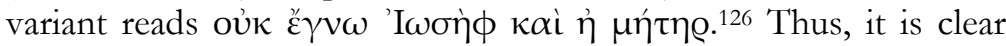
that the Vorlagen of $\mathrm{P}, \mathrm{Ph}$, and $\mathrm{H}$ attest to the latter variant reading, though the translators of $\mathrm{Ph}$ and $\mathrm{H}$ have attempted to translate the word order more precisely. It also appears that the translator of $\mathrm{Ph}$ has attempted to translate the third person singular $\varepsilon^{\prime} \gamma \nu \omega$ by using איד: rather than the third person plural o. It is unclear whether or not the Greek text behind the text of $\mathrm{H}$ included a singular or a plural verb, though given the systematic pursuit of word-for-word translation throughout the text of $\mathrm{H}$, including verb tense and person, it can be assumed that the Vorlage(n) of $\mathrm{H}$ had the plural verb.

${ }^{124}$ CPJ 209.13-14

125 The witnesses that attest to this reading are: $\mathrm{NB} \mathrm{D} \mathrm{L} \mathrm{W} \theta \mathrm{f}^{1} 33$. 579. lat sa

126 The witnesses that attest to this reading are: A C $\Psi 0130 f^{13}$ it bopt. 


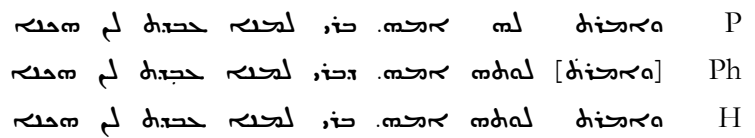

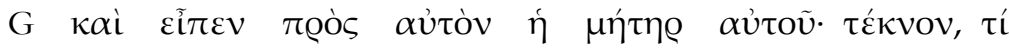

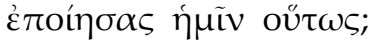

In this citation, ${ }^{127}$ the translator of $\mathrm{Ph}$ replaces the preposition -J with the independent preposition dal as the translation of the Greek preposition reós. The texts of $\mathrm{Ph}$ and $\mathrm{H}$ consistently demonstrate this same revision in other verses, so it is reasonable to conclude that this minor revision is in fact part of the text of Ph. The citation shown above omits the initial $-a$, but we need not conclude that the text of $\mathrm{Ph}$ omitted it because it is likely that Philoxenos simply omitted it based on the context in which he quoted the verse. The citation also adds a $-\boldsymbol{x}$ to the beginning of the word diss in order to introduce direct discourse. It is possible that this addition is part of the text of $\mathrm{Ph}$, but the translator of $\mathrm{H}$ does not include this revision, so we have no external evidence to support this conclusion.

$2: 52$

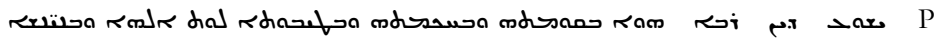

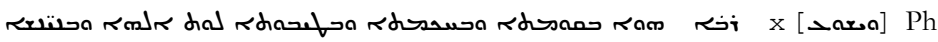

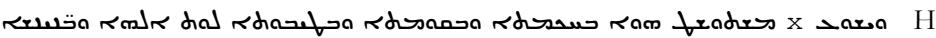

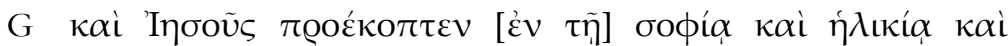

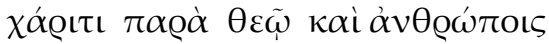

Philoxenos quotes this verse eight times, and although only two of these quotations are found in CPJ, five of the remaining six are

127 CPJ 209.15-16. There is a citation from CML that incorporates the latter portion of this verse, but it is omitted from this section for three reasons: 1) the portion discussed above is not included in the citation from $C M L$; 2) the citation from $C M L$ is found only in later (13th century) mss, and is thus not as reliable as CPJ; and 3) the text of the citation from $C M L$ accurately represents the text of $\mathrm{P}$, so there is no need to include it here. 
found in MS A, the earliest witness for CML.128 Philoxenos displays an intent to cite with the citation marker 7 in three of the citations ${ }^{129}$ and introduces the text of the citation found above with the phrase, م.x, as does the text of $\mathrm{H}$. This is likely an intentional omission by the translators because there is no post-positive conjunction in the Greek text. The verse in Greek does begin with $\kappa \alpha$ í, and the translator of $\mathrm{H}$ has added $-\mathrm{a}$ to the first word to account for this. The $-a$ does not appear in any of the citations of $\mathrm{Ph}$, but it is not necessary to conclude that the text of $\mathrm{Ph}$ omits this conjunction because the citations begin here and the $-a$ is not necessary. The only other alteration of the text of $\mathrm{P}$ found in $\mathrm{Ph}$ is the omission of

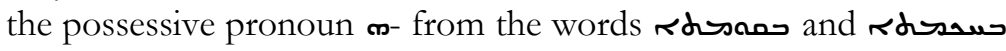
("stature" and "wisdom"). It is not clear why these pronouns were used originally, as they are unnecessary; and this is likely the reason for their omission in the text of $\mathrm{Ph}$ and $\mathrm{H} .{ }^{130}$ One citation of this verse does display the transposed word order of $\mathrm{H}$ for these two words, ${ }^{131}$ but six citations contain the word order found above. Thus, it seems most likely that the text of $\mathrm{Ph}$ retained the word order of $\mathrm{P}$ and that Philoxenos accidentally transposed the words in one citation.

$3: 23$

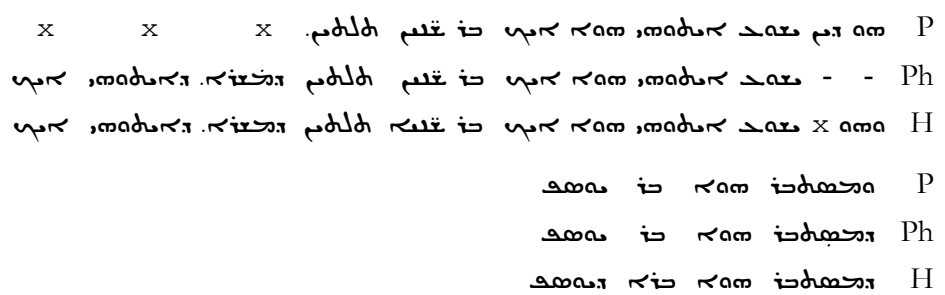

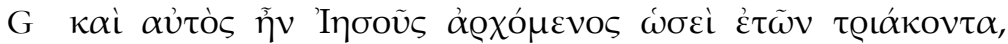

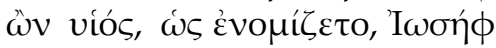

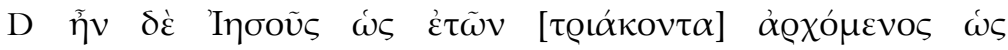

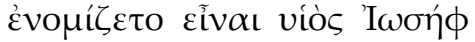

${ }_{128}$ CPJ 71.25-26; 184.29-185.2; CML 44.22; 53.2-4; 53.5; 54.8-9.

${ }^{129}$ CPJ 71.25-26; CML 54.8-9; 65.13-14.

130 Philoxenos does retain this possessive on mol in one brief allusion to this verse: CML 44.22.

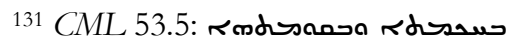


In Philoxenos' commentaries there are six citations of this verse, though only one contains the whole verse, and this full citation is the only one found in CPJ..$^{132}$ The text of Philoxenos' citation begins with the word מعح , so we cannot conclude whether or not the text of Ph omitted and included $-\mathrm{a}$ at the beginning of the verse as the text of $\mathrm{H}$. The texts of $\mathrm{Ph}$ and $\mathrm{H}$ have added the

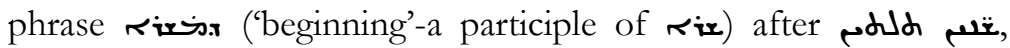
most likely as an attempt to render the Greek participle

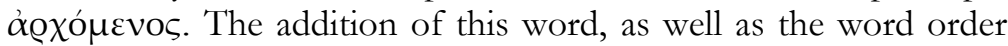
of all three texts, presents an interesting problem: none of the three texts reflect a word-for-word translation of the word order of the Greek text as it stands in $\mathrm{NA}^{27}$. This is not surprising with regard to the text of $\mathrm{P}$, but it is surprising with regard to the texts of $\mathrm{Ph}$ and $\mathrm{H}$. However, there is a variant reading for this verse that could explain the variation in word order. Although the word order of the texts of $\mathrm{Ph}$ and $\mathrm{H}$ does not correspond precisely to that of $\mathrm{D}$, it is much closer to its order than to that of the $\mathrm{NA}^{27}$ critical text.

With the exceptions of placing the verbal phrase ram , madur (the translation of $\tilde{\eta} v$ ) after the subject (Jesus) rather than before it, and, similarly, placing the verb ,madurs (the translation of eĩval) before the clause ram irdoass wor (the translation of $\omega s$

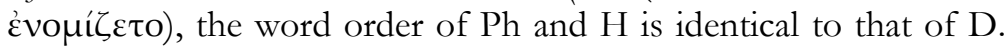
Moreover, there is some question about the word order of the text of $\mathrm{Ph}$ with regard to the placement of madurax in the text. One of the five shorter citations ${ }^{133}$ renders the final phrase ram ivios (لo . The word order of this citation is precisely equal to the word order of $\mathrm{D}$. This citation comes from CML, but it is found in the portion of the text attested by MS A and is thus quite likely to be authentic. Moreover, this quotation includes the citation marker ol. The change in word order is more easily explainable in this shorter citation, as it is more likely to have been altered to Philoxenos' style. However, either way the word order of the text of $\mathrm{Ph}$ is closer to the word order of $\mathrm{D}$ than it is to $\mathrm{NA}^{27}$. Thus, it appears that there is a link between the Vorlage(n) of $\mathrm{Ph}$ and $\mathrm{H}$ and the text to which Codex $\mathrm{D}$ attests for this verse. This claim is tentative, but based on the word-for-word translation

132 Full: CPJ 41.6-8; Partial: CML 80.27; 81.9; 82.19-20; 84.4; 87.6.

${ }^{133}$ CML 80.27. 
technique of the translator of $\mathrm{H}$, and to a lesser but still notable degree, the translator of $\mathrm{Ph}$, the claim is defensible.

\subsection{Philoxenian Gospel of John}

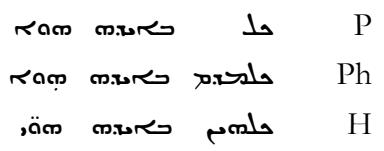

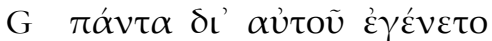

While this citation is only a short portion of the text of Jn 1:3, we may confidently attribute this text to the Philoxenian version. Philoxenos cites this portion of the verse four times, ${ }^{134}$ and in one of the four he includes the citation marker 135 Moreover, all four

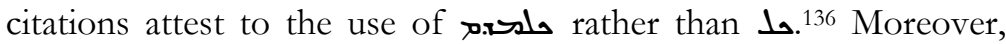
shis also found in three separate citations of this verse in the writings of Cyril of Alexandria, so it is clear that this reading was used in other fifth/sixth century translations. ${ }^{137}$

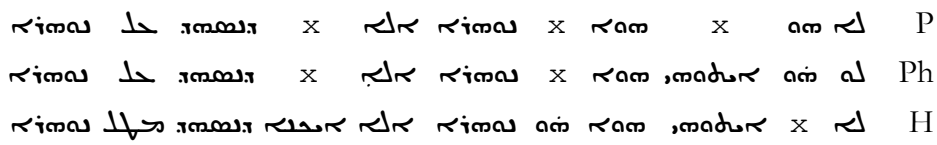

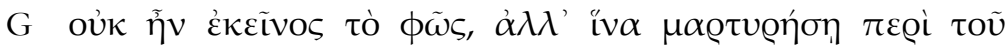
$\phi \omega \tau o ́ s$

In the one citation of this verse, ${ }^{138}$ the text of $\mathrm{Ph}$ adds the verbal phrase emador to rom, in an attempt to translate more precisely the Greek aorist verb ĩv. This translation style is characteristic of $\mathrm{Ph}$, and the revision is retained in $\mathrm{H}$, so it is reasonable to conclude

${ }^{134}$ CPJ 140.11-12; 132.13-14; 213.4-5; 241.18.

135 CPJ 140.11-12.

136 The citation of this verse in LMS 4.17-19 also reads هـ דביד. The OS C also contains מلs., so it is possible that this reading was retained in Philoxenos' version of $\mathrm{P}$.

137 King, Syriac Versions, 430.

${ }^{138}$ CPJ 241.21-22. 
that this is the reading of $\mathrm{Ph}$. However, there is some question about attributing the negative particle $\mathrm{d}$ at the beginning of the sentence to the Philoxenian version. Pusey and Gwilliam do not list $\mathrm{d}$ as a textual variant for 1:8, and neither the Peshitta nor the Harclean version displays this reading. This evidence does not preclude the possibility that the text of $\mathrm{Ph}$ included $\mathrm{d}$; it simply means that there is no other external evidence to validate this reading. It is even possible that this reading was found in Philoxenos' text of $\mathrm{P}$ and that this variant simply was not included in the critical edition. Thus, we may tentatively conclude that $\mathrm{d}$ is found in the text of $\mathrm{Ph}$.

1:10

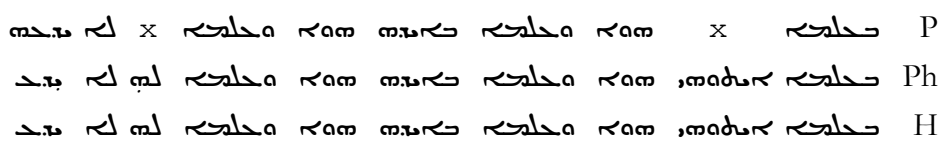

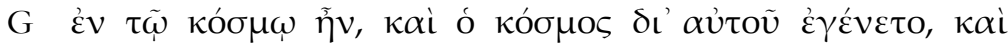

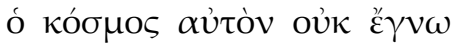

The text of this verse is part of a lengthy citation comprised of Jn 1:10-13, , $^{139}$ though there are also two other partial citations of this verse as well. ${ }^{140}$ Philoxenos indicates his intention to cite with the citation marker له a (a) and introduces the citation with the phrase "the evangelist wrote and said thus concerning him" (....). As with Jn 1:8 above, the text of $\mathrm{Ph}$ adds the verb, madur to ram in order to translate the verb $\tilde{\eta} v$, and the Harclean version includes this revision as well. The other variation of the text of $\mathrm{Ph}$ from the text of $\mathrm{P}$ in this verse is the replacement of the direct object pronoun m- with the independent direct object on in the final phrase of the sentence. This variation does not change the meaning of the phrase, but it does reflect the Greek word order ( $\alpha \dot{u} \tau o \dot{v}$ oùk $\varepsilon \gamma \gamma \nu \omega)$. The Harclean version also includes this revision.

${ }^{139}$ CPJ 38.1-3.

${ }^{140}$ CPJ 38.10; 38.11. 


\begin{tabular}{|c|c|c|c|c|c|c|c|}
\hline $\mathrm{x}$ & محلمه, & ه & م.0له & $x$ & rdir & له.مله & $x$ \\
\hline $\mathrm{x}$ & محلمهו, & 山 & זمله & مهم & rdpr & ل.مله & $\mathrm{x}$ \\
\hline & $\mathrm{x}$ & 山 & ه.مله & வ் & rdir & xله & لهمل \\
\hline
\end{tabular}

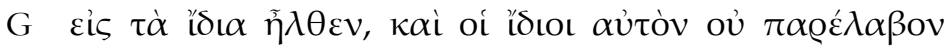

Philoxenos cites this verse with the same wording on two occasions in CPJ, and he uses the citation marker $>$ for both. ${ }^{141}$ The first is part of a long quotation from Jn 1:10-13, and the second citation comes from the discussion following this quotation. The only revision in the text of $\mathrm{Ph}$ from $\mathrm{P}$ is the addition of the demonstrative pronoun $\mathbf{N}$ ma. This addition does not necessarily conform more closely to Greek word order, but it seems to be an attempt to translate the Greek plural oi ísı because the Syriac mb. does not reflect the plural antecedent. Although the text of $\mathrm{H}$ displays the pronoun rather than in order to distinguish the gender, these translations are virtually equivalent, and it appears that the translators had similar intentions. ${ }^{142}$

$1: 14$

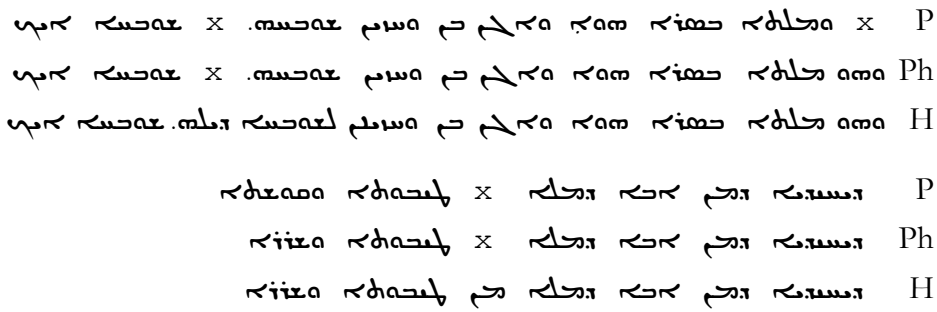

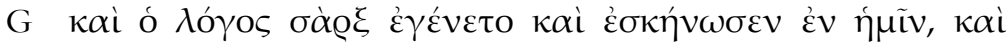

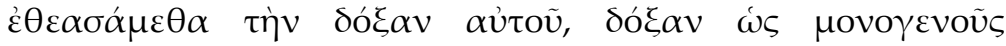

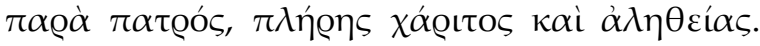

${ }^{141}$ CPJ 38.3-4; 38.14-15.

142 The text of $\mathrm{H}$ takes this concept one step further by adding at the beginning of the sentence to reflect the other Greek plural in the first phrase of the verse ( $\tau \dot{\alpha} \mathrm{i} \delta \mathrm{\iota} \alpha)$. 
The task of determining the Philoxenian version of Jn 1:14 is extremely complex because Philoxenos quotes some portion of this verse over 50 times throughout his commentaries and his wording is inconsistent. Moreover, despite the fact that he refers to this verse so many times, Philoxenos never quotes the full verse in any one place. Thus, we are left with the task of reconstructing his wording from partial citations. Such a task is tenuous, but the high number of citations, varied though they may be, actually make such a reconstruction possible.

The inclusion of the pronoun an at the beginning of the phrase is questionable because of the 50 citations in the commentaries that include the opening phrase only twelve have it. ${ }^{143}$ We cannot appeal to citation markers or intent to cite in this case because Philoxenos uses the citation marker ot in citations with and without am. The particle an is found in the text of $\mathrm{H}$, and clearly represents an attempt to represent the Greek definite article ó. King asserts that "most of his [Philoxenos'] allusions do not allow for" the inclusion of am. ${ }^{144}$ While this is true, it is tenuous to use allusions to establish accurate citations. Moreover, as is true for the use of Greek witnesses in textual criticism, we cannot allow the sheer number of occurrences of a variant to determine the original. The fact that Philoxenos quotes Jn 1:14 so many times suggests that he was highly concerned about the interpretation of this verse, and the addition of an emphasizes and helps to clarify the subject of the verse. Moreover, there is evidence of this same translation technique elsewhere in Ph. ${ }^{145}$ Therefore, it seems reasonable to conclude that the text of $\mathrm{Ph}$ also includes an here as a translation of the Greek article. ${ }^{146}$

There is some question about the word order of rim ram in Philoxenos' citations of this verse because he frequently conforms it to the more idiomatic Syriac word order of VerbSubject-Object, rendering the phrase rim rabs ram. However,

143 This reading is also found in three of the four citations containing this portion of the verse found in Tract. tres $(120.7 ; 143.14-15 ; 239.24-25)$.

144 King, Syriac Versions, 431.

145 See the discussion above of Mt 2:2.

${ }^{146}$ It should be noted that none of the citations of this verse in $L M S$ contains am, but all of these citations are either allusions or very brief (usually only the opening phrase). 
despite the frequency with which Philoxenos provides this wording, it may be concluded that citations with this word order are properly classified as allusions-Philoxenos is clearly referring to the language and ideas of a particular verse, but he has altered the wording to fit his own context.

Philoxenos omits the conjunction - $\mathrm{a}$ each time he cites the portion of the text that includes ww, but this should not necessarily lead to the conclusion that it does not exist in Ph. Philoxenos cites this portion of the text five times, and all five of these citations begin with the word wמה. Thus, when Philoxenos cites this portion of the verse, he is not doing so in continuation from the first part of the verse, rendering the $-a$ unnecessary. ${ }^{147}$

The text זمحس as is also in question because Philoxenos cites both wordings in close proximity to one another in CPJ..$^{148}$ However, Philoxenos does include the citation marker $>$ with the former wording, and this citation is longer than the citations that read בaحسم, providing some evidence that the longer rendering is actually in the text of $\mathrm{Ph}$. The translation is a more literal rendering of the Greek word order $\delta o ́ \xi \alpha \nu \alpha \hat{v} \tau o \tilde{v}$, but this type of revision is not characteristic of the translation technique of $\mathrm{Ph} .{ }^{149}$ However, the existence of the reading ratang the citations of Philoxenos must be explained somehow because it is not typical of idiomatic Syriac. It has already been noted that Philoxenos quotes this verse over fifty times, so it is highly likely that the wording of this verse received more attention than other verses. Thus, it is possible that the more literal reading ras was originally part of the text of $\mathrm{Ph}$ simply because of the attention that Philoxenos paid to its interpretation. Thus, it is reasonable to conclude that the text of $\mathrm{Ph}$

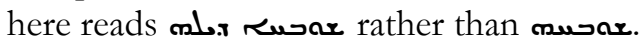

${ }^{147}$ Moreover, P. J. Williams asserts that the presence or absence of - $\mathrm{a}$ should not reflect whether or not there is a $\kappa \alpha i$ in the Greek Vorlagen. Williams, Early Syriac Translation Technique, 149-159.

148 CPJ 239.7-9; 240.24-25.

${ }^{149}$ Aside from this citation, there are eighteen occasions for which we have the text of $\mathrm{Ph}$ in which the translation of $\mathrm{H}$ replaces an enclitic possessive pronoun with the independent possessive particle, and in all eighteen cases the text of $\mathrm{Ph}$ agrees with $\mathrm{P}$ against $\mathrm{H}$. 
Philoxenos quotes the final phrase of the verse three times, and

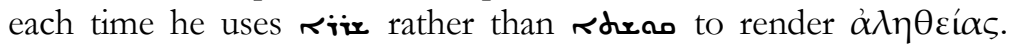
This reading is one of the few cases in which the text of Ph agrees with one of the OS texts (in this case, C) over and against the text of P. Pusey and Gwilliam do not list rive as a variant, though it is possible that the Peshitta text with which Philoxenos was familiar retained riv from the text of the OS, though this must remain uncertain. However, it is not necessary to conclude that Philoxenos' text of $\mathrm{P}$ included rive, as it is likely a lexical revision by the translator of $\mathrm{Ph}$ to offer a more accurate translation. The text of $\mathrm{H}$ also includes rix rather than مar, adding further support to the case that the text of $\mathrm{Ph}$ read rivir as well.

$1: 15$

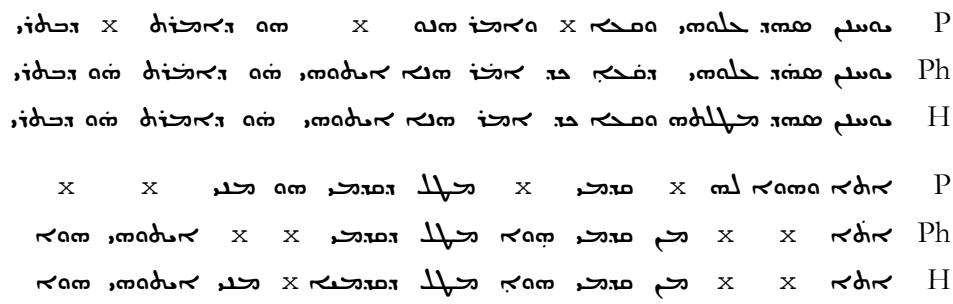

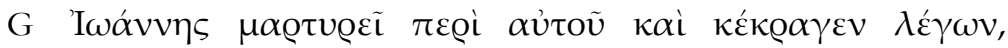

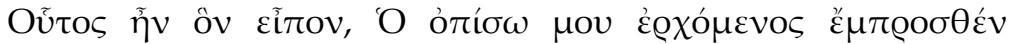

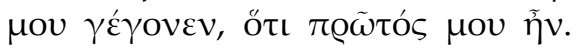

Philoxenos quotes the full version of 1:15 twice t50 $^{150}$ and cites phrases of the verse twice as well. ${ }^{151}$ In one of the two full citations, Philoxenos provides the citation marker $7 .{ }^{152}$ While there are minor variations among Philoxenos' quotations, they are similar enough to confidently attribute the reading above to the text of Ph. There are several additions within the text of $\mathrm{Ph}$ that appear to be the result of providing a more precise translation: the addition of the temporal preposition $\boldsymbol{\Delta}$ to the participle isr, the addition of the verbal phrase, madur as a translation of $\tilde{\eta} v$, and the addition of the pronoun an as a literal translation of the Greek definite

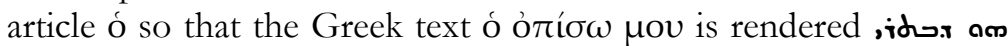

\footnotetext{
${ }^{150}$ CPJ 231.13-15; 242.16-17.

151 CPJ 242.2; 242.22-23.

152 CPJ 241.13-15.
} 
(though $a m$ is functioning grammatically as a pronoun). The text of $\mathrm{Ph}$ also places the verb ram after the preposition 0 to match

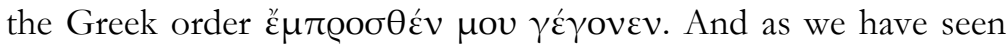
elsewhere, the text of $\mathrm{Ph}$ adds the full verbal phrase ram ,madur at the end of this sentence to reflect the Greek verb $\tilde{\eta} v .{ }^{153}$

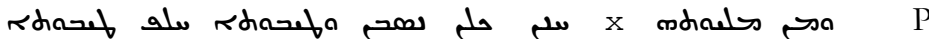

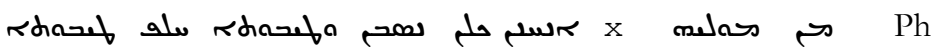

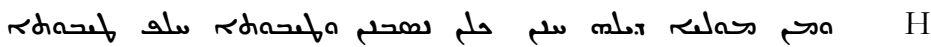

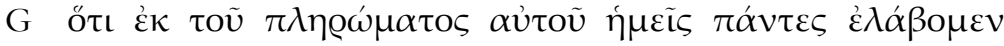

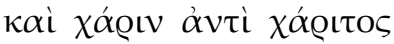

Philoxenos' commentaries contain one full ${ }^{154}$ and two partial ${ }^{155}$ citations of this verse. The revisions are slight: the text of $\mathrm{Ph}$ replaces rdads with the virtually identical ridos, both derivatives of the verb s s. It is also interesting to note that while

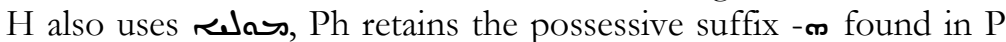
order to reflect the use of the Greek $\alpha \dot{v} \tau o \tilde{v}$ whereas the text of $\mathrm{H}$ uses the extended mb.x. The text of $\mathrm{Ph}$ also provides the extended form of the first person plural pronoun אحسف. Philoxenos quotes this precise wording on two different occasions, and one of the citations includes 7 , so it is reasonable to conclude that this is the wording of $\mathrm{Ph} .{ }^{156}$

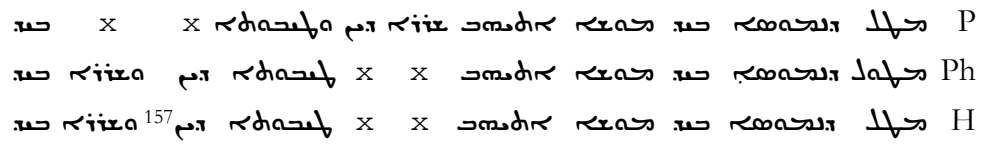

153 Jn $1: 8,10$.

154 CPJ 245.5.

155 CPJ 245.20-21; 245.27

156 This word is marked with an asterisk and obelus in the Harclean tradition to denote Thomas's insertion of a word not found in his Greek Vorlagen. For the explanation of these sigla, see Juckel, "Introduction to the Harklean Text" in G. Kiraz, Comparative Edition of the Syriac Gospels, Vol. 1: Matthew, xxxiii-xxxv. 


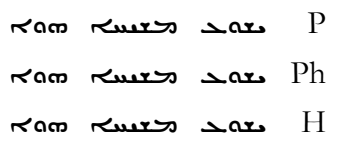

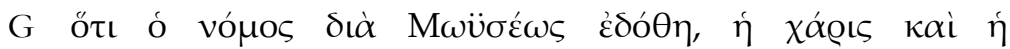

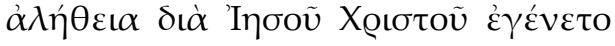

Philoxenos provides two quotations of this verse, and both reflect the wording found above. ${ }^{157}$ In order to provide a word-for-word

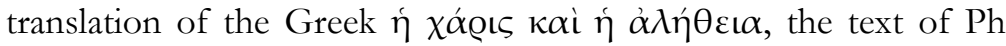
inverts the word order of rivi and rdicle ה.

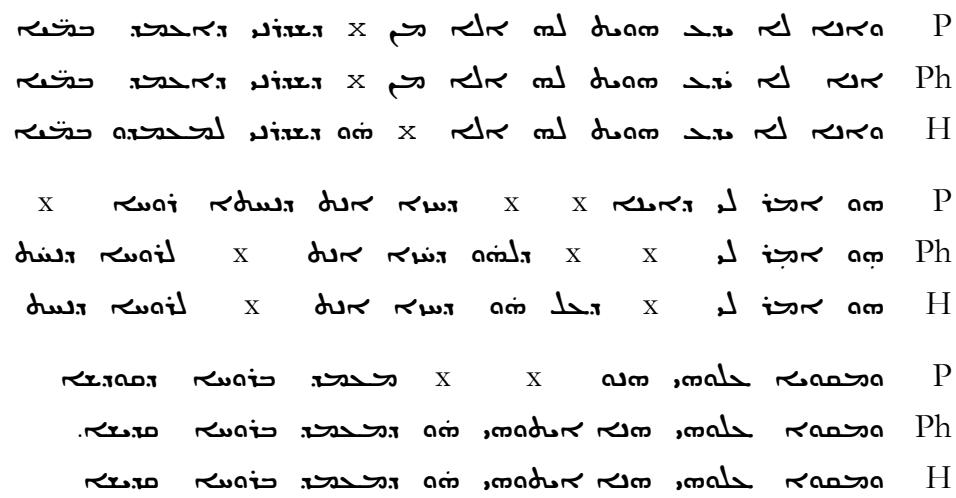

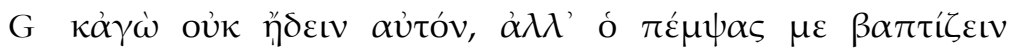

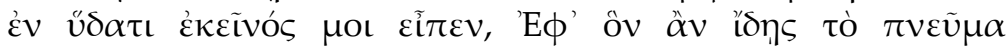

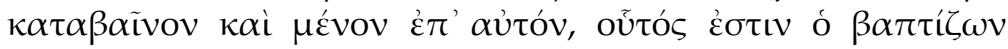

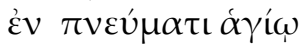

Philoxenos cites this verse only once, but he quotes the whole verse. ${ }^{158}$ The text of $\mathrm{Ph}$ omits the pronoun with aid. The change in meaning in this phrase is not drastic, though it is likely an attempt by the translator of $\mathrm{Ph}$ to render more literally the Greek prepositional phrase 'E $\phi$ ' óv. It appears also that the text of $\mathrm{H}$ attempts to render this phrase even more literally with the phrase ar ar. Thus, the translation of this phrase is an

\footnotetext{
157 CPJ 245.6-7; 246.27-28.

158 CPJ 216.8-11.
} 
example of the intermediary status of the translation of $\mathrm{Ph}$ between $\mathrm{P}$ and $\mathrm{H}$. The text of $\mathrm{Ph}$ also alters the word order of the phrase ruai r.w. to read dw.

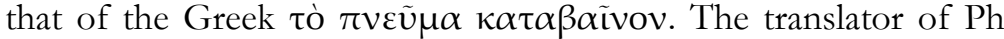

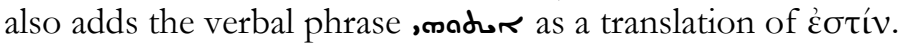

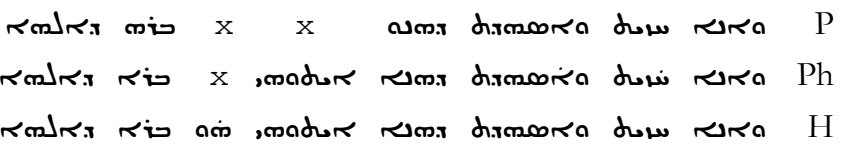

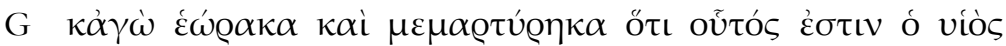

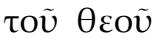

In the citation of this verse, ${ }^{159}$ the text of $\mathrm{Ph}$ adds the verbal phrase smadur in order to reflect the presence of the Greek verb k̇ $\sigma \tau$ ív. This type of revision is characteristic of the translation technique of $\mathrm{Ph}$, and the text of $\mathrm{H}$ also displays this translation, so it is reasonable to conclude that this revision represents the text of $\mathrm{Ph}$.

\section{3:16}

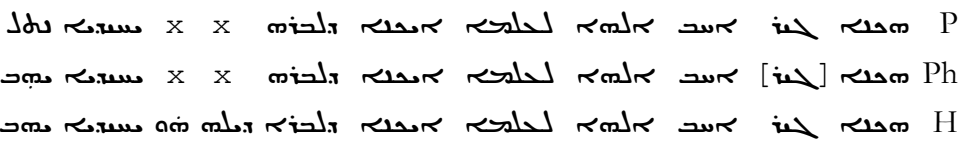

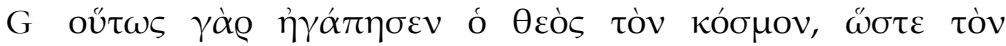

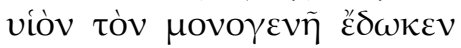

There are three full citations of this verse in Philoxenos' writings. ${ }^{160}$ All three citations lack the conjunction it though it is not necessary to assume that it is missing from the text of $\mathrm{Ph}$ because one of the citations includes $>$ in the place of $\boldsymbol{w}^{161}$ and the omission is likely accidental or the result of adaptation to Philoxenos' citation context. All three citations of this verse demonstrate a change in the verb from Jdu to מח Despite the fact that the spelling of these words differs significantly, Jdu is a defective form of sm. Thus, it appears that this revision is an

${ }^{159}$ CPJ 216.11-12.

${ }^{160}$ CML 74.5-6; 78.11-12 (both in MS A); LMS 28.15-17.

161 Though the citation in LMS contains 
attempt by the translators of $\mathrm{Ph}$ and $\mathrm{H}$ to render more literally the perfect tense of the Greek verb ह̌ $\omega \omega \kappa \varepsilon v .^{162}$ All of Philoxenos' citations of this verse conclude with the addition of the word ("On account of it [i.e. the world]"). ${ }^{163}$ However, it is not necessary to conclude that this word was included in the text of $\mathrm{Ph}$ because each citation ends here and does not continue on to include 3:17. Thus, the inclusion of ,malu is likely an attempt to "resolve" the verse and make it coherent as a self-contained thought.

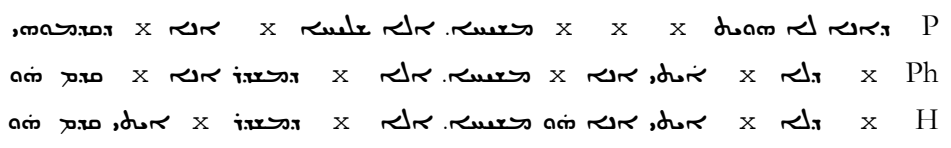

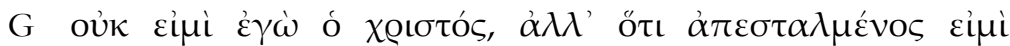

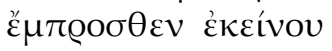

Philoxenos only quotes the second half of this verse, ${ }^{164}$ but the portion that he does quote reflects revisions characteristic of other citations from $\mathrm{Ph}$. The text of $\mathrm{Ph}$ replaces the verb donom with the verbal phrase wr dor. The text of $\mathrm{H}$ also includes this reading, though it adds the pronoun an to reflect the presence of the Greek definite article. The text of $\mathrm{Ph}$ also replaces ruev with the verbal phrase ins s, which seems to be a more accurate translation of the Greek participle $\alpha \pi \varepsilon \sigma \tau \alpha \lambda \mu \varepsilon \dot{v}$ os. Once again, the text of $\mathrm{H}$ reproduces the variant reading found in $\mathrm{Ph}$, though it replaces the first person singular pronoun wr with the verb dor in the final phrase.

162 Though it is also worth noting that Jdu also appears in OS C and in the citation of this verse in the Syriac translation of Cyril, so it is possible that Philoxenos inherited this reading. King, Syriac Versions, 437438.

163 Including the three citations mentioned above and three additional citations found in Tract. tres.

${ }^{164}$ CPJ 216.13-14. 


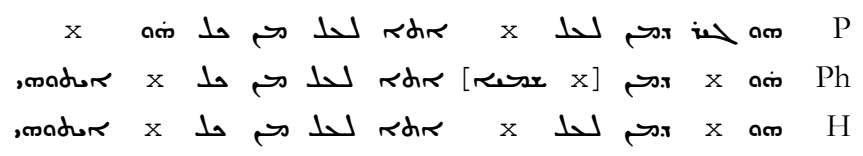

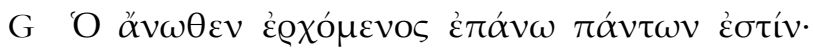

In the brief citation of this verse, ${ }^{165}$ the text of $\mathrm{Ph}$ and the text of $\mathrm{H}$ omit the conjunction iw likely because there is no conjunction in the Greek text. In the final phrase, the text of $\mathrm{Ph}$ replaces the

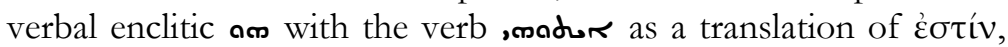
and the text of $\mathrm{H}$ also reflects this revision. In addition to these two revisions which seem to fit the translation technique of $\mathrm{Ph}$, this quotation also reads ("heaven") rather than ("above"). Without external validation, either from its inclusion in the text of $\mathrm{H}$ or a second citation with the same wording, it is tenuous to conclude that the text of $\mathrm{Ph}$ actually read ras. And while it is possible that that Philoxenos (or the translator of $\mathrm{Ph}$ ) thought that was a better translation in this context than $\boldsymbol{W}$, this does not seem likely as $\boldsymbol{W}$ is the more "literal" translation of $\ddot{\alpha} v \omega \theta \varepsilon v$. Thus, it seems more likely that this is a mistake of memory or an adaptation by Philoxenos and should not be considered part of the text of $\mathrm{Ph}$.

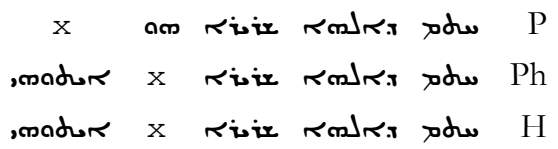

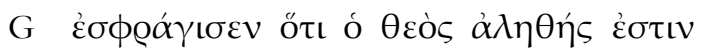

Philoxenos' quotation of this verse is only a portion of the longer verse, ${ }^{166}$ but the translation technique in this brief citation is consistent with that of $\mathrm{Ph}$ elsewhere. The text of $\mathrm{Ph}$ replaces an with ,madur as a translation of the Greek word $\dot{\varepsilon} \sigma \tau \mathrm{\tau} v$ at the end of the verse. The text of $\mathrm{H}$ also retains this reading, so it is reasonable to conclude that this is the text of $\mathrm{Ph}$.

\footnotetext{
165 CPJ 216.21.

166 CPJ 216.22-23.
} 


\section{$5: 34$}

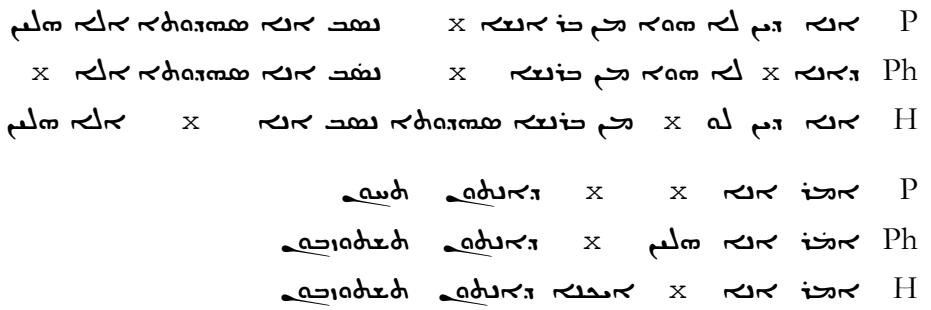

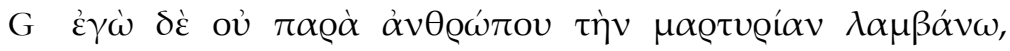

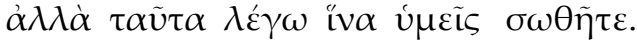

The text of 5:34 in Philoxenos' citation ${ }^{167}$ is nearly identical to the text of $\mathrm{P}$, though the difference between them is enough to justify categorizing this verse as a citation of $\mathrm{Ph}$. The revision in word order of מת is inconsequential, and because it is not reflected by $\mathrm{H}$ or by the Greek text, there is little evidence to demonstrate that the actual text of $\mathrm{Ph}$ reflected this reading. However, because the text of $\mathrm{Ph}$ frequently demonstrates a revision toward the Greek word order, the possibility remains that the Vorlage of the text of $\mathrm{Ph}$ had the word order $\lambda \dot{\varepsilon} \gamma \omega \tau \alpha \tilde{v} \tau \alpha$. It is also possible that Philoxenos simply made a mistake with regard to the placement of there is evidence of another revision characteristic of $\mathrm{Ph}$ at the end of the verse. The text of $\mathrm{Ph}$ changes the verb from awd to aradxh (from Ear, Ethp: 'to be delivered') and revises the voice of this verb from active to passive in order to render literally the Greek passive verb $\sigma \omega \theta \tilde{\eta} \tau \varepsilon$. The text of $\mathrm{H}$ also includes this reading. 


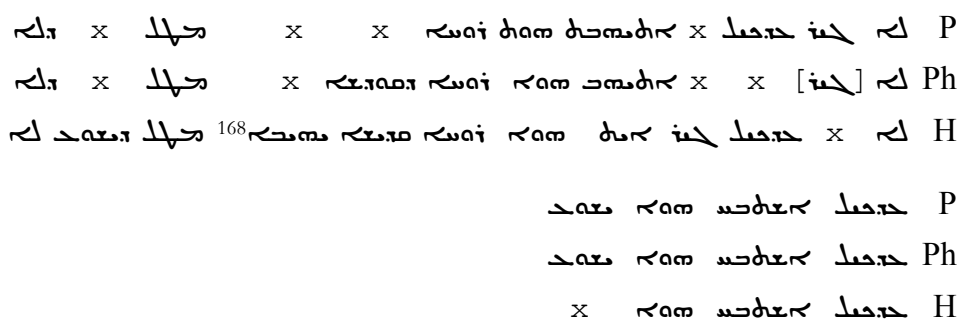

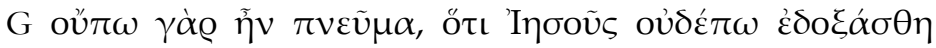

Philoxenos quotes this verse only once, ${ }^{169}$ but he includes the citation marker لor. As he often does, Philoxenos places od in the position of the post-positive conjunction, so although the citation does not include $\sim$ we should not necessarily conclude that it was omitted from the text of $\mathrm{Ph}$. It is possible that the omission of ح.a in the text of $\mathrm{Ph}$ was intentional because the Greek word oú $\pi \omega$ carries the meaning of the Syriac phrase $ه$. Thus, it is possible that the text of $\mathrm{Ph}$ represents an attempt at a word-forword correspondence and omitted ح.a. This explanation is supported by the fact that the texts of $\mathrm{P}, \mathrm{Ph}$, and $\mathrm{H}$ all display a longer form of this text including a form of the verb sm ("to give”). This appears to be a result of a textual variant, as several witnesses include the phrase $\pi v \varepsilon \tilde{v} \mu \alpha$ ó $\gamma$ tov $\delta \varepsilon \delta$ ó $\mu \varepsilon v o v .{ }^{170}$ Thus,

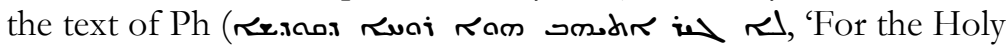
Spirit had not been given') represents a translation of the variant reading. The text of $\mathrm{Ph}$ also includes a revision in the gender of the verb smodr from feminine to masculine in order to represent the Holy Spirit as male, not female. ${ }^{171}$

168 This word is marked with an asterisk and obelus in the Harclean tradition to denote Thomas's insertion of a word not found in his Greek Vorlagen. See n. 156 above.

${ }^{169}$ CML 52.17-18. This citation comes from MS A.

170 The witnesses that include this variant are B pc e q sy ${ }^{\mathrm{h}}$

171 See the discussion of this aspect of Syriac translation technique in Lk 1:35. 


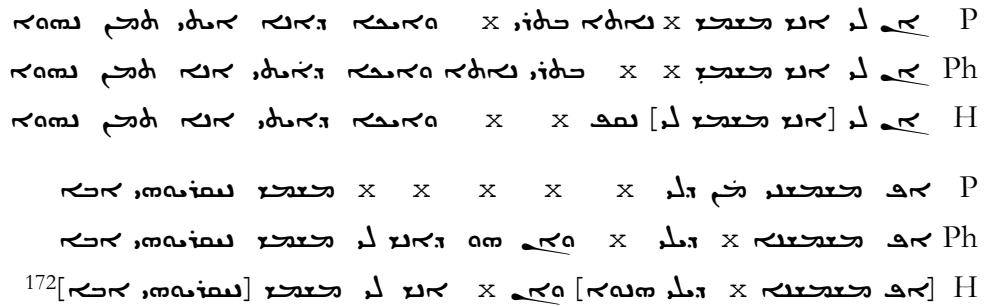

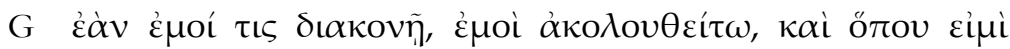

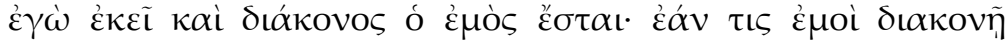

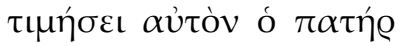

In the citation of this verse from $C P J,{ }^{173}$ the text of $\mathrm{Ph}$ inverts the word order of the phrase, idu rdirs in P. While this is essentially an inconsequential revision, the text of $\mathrm{Ph}$ matches the Greek $\varepsilon \mu$ iो

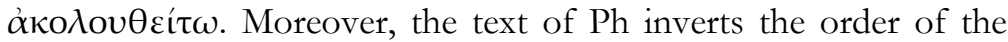
phrase dur w in order to reflect more accurately the Greek text. The text of $\mathrm{H}$ also displays this revision. The phrase an ro $\checkmark$ עr in the text of $\mathrm{Ph}$ is not found in the text of $\mathrm{P}$, but the text of $\mathrm{H}$ retains this reading (with the exception of $\mathrm{am}$ ). Thus, the text of $\mathrm{Ph}$ appears to be an attempt at a more word-for-word translation of the Greek text.

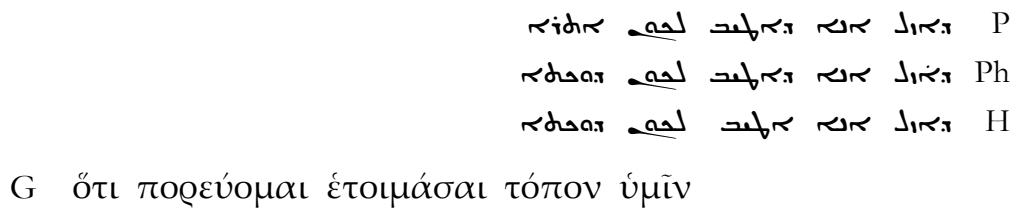

172 The brackets in the Harclean text here, as found in the Comparative Edition of the Syriac Gospels, denote that these words are ineligible in the primary manuscript used for the Harclean text (Vat. Syr. 268), and that these words come from Vat. Syr. 267. G. Kiraz, "Introduction to the CESG," in idem., Comparative Edition of the Syriac Gospels, Vol. 1: Matthew, xxv.

${ }^{173}$ CPJ 210.9-12. 
The only revision in this citation ${ }^{174}$ is the replacement of ridr with the virtually equivalent rdana. The text of $\mathrm{H}$ and a citation in the Syriac translation of Cyril ${ }^{175}$ also display this reading, providing support for its existence in the text of $\mathrm{Ph}$.

$14: 3$

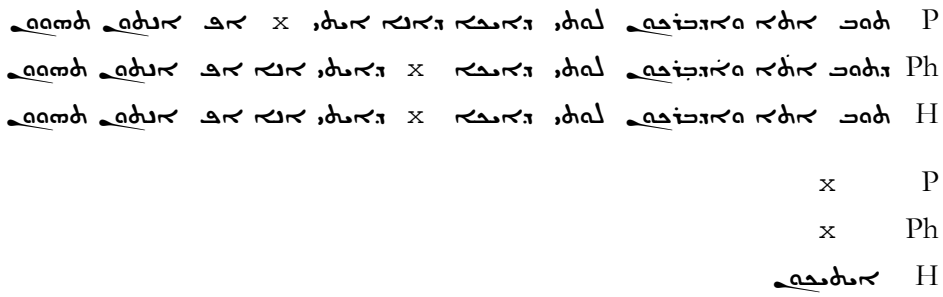

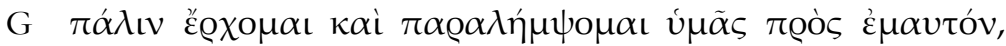

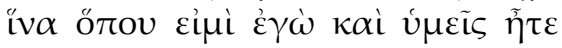

In this citation, ${ }^{176}$ the text of $\mathrm{Ph}$ reflects the inverted word order of

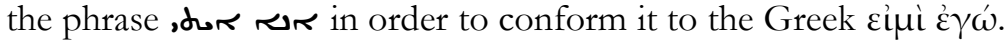
This reading is also found in the text of $\mathrm{H}$.

16:12

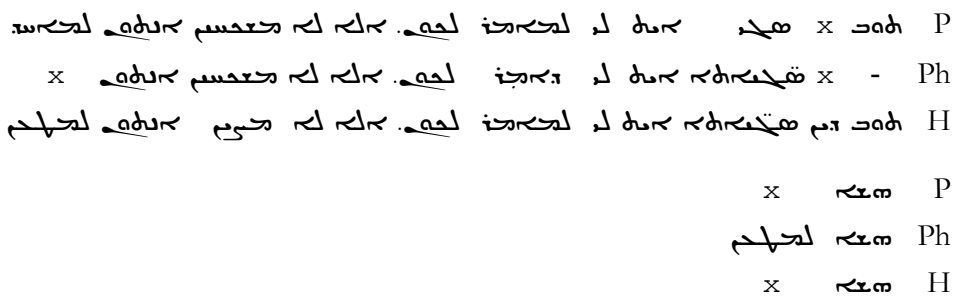

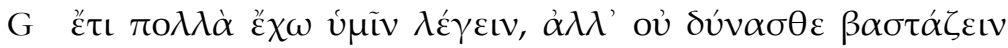

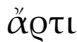

Philoxenos' exegetical writings contain three full citations of this verse, and all three include citation markers. ${ }^{177}$ The three citations are not identical, but they demonstrate a high level of similarity. All three of Philoxenos' citations read xrather than the infinitive

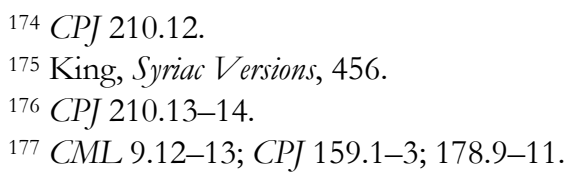


Sבras found in P and H. All three quotations also include rather than s as found in H. Indeed, the three quotations from Philoxenos are in perfect unison until the final phrase. Two of the quotations agree with the text of $\mathrm{P}$ with regard to content and to

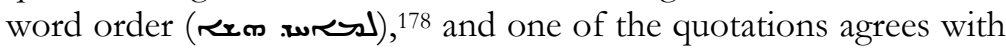

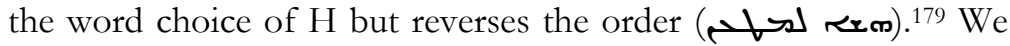
are not able to appeal to the authority of one commentary over and against the other, however, as each reading appears in CPJ. It seems that the most obvious answer is to allow majority to rule and to assume that the text of $\mathrm{Ph}$ agrees with the text of $\mathrm{P}$. However, this explanation does not account for the fact that the text of $\mathrm{H}$ displays the variant reading that would be dismissed if $\mathrm{Ph}$ agrees with P.

There are also a few possible explanations for the difference between the texts. It is possible that the text of $\mathrm{Ph}$ included the reading 2 d but Philoxenos accidentally reverted back to the text of the Peshitta two of the three times he wrote this verse. After all, there is no major christological issue at stake in this change in translation, so it could be assumed that Philoxenos could quite easily forget that this word had been changed. Moreover, it is possible that a scribe altered (intentionally or not) the text of any of the three citations to conform it to the more familiar text. Despite the fact that both disputed words are included above in brackets to illustrate some amount of uncertainty, it seems more likely that the text of Ph originally read $\forall$ secause this best explains the use of the same word in the text of H. ${ }^{180}$

178 CML 9.12-13; CPJ 178.9-11.

${ }^{179}$ CPJ 159.1-3.

180 Brock asserts that Jn 16:12-13 “excellently illustrates Ph's intermediary position" between $\mathrm{P}$ and $\mathrm{H}$, "Resolution of the Philoxenian/Harclean Problem," 331. 
$16: 13$

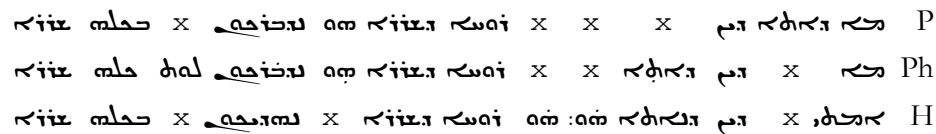

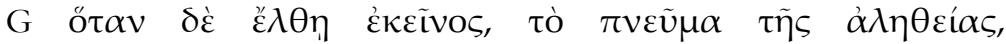

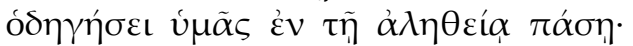

Philoxenos quotes this verse four times with two full 181 and two partial citations. ${ }^{182}$ The text of $\mathrm{Ph}$, along with the text of $\mathrm{H}$, places r. $\mathrm{x}$ before the verb $r d \boldsymbol{r}$, reflecting the placement of $\delta \varepsilon \dot{\varepsilon}$ in the Greek text. Two of the four citations of this verse in Philoxenos include this reading; ${ }^{183}$ one omits the conjunction altogether; ${ }^{184}$ and one replaces $x$ with 1.185 However, Pusey and Gwilliam also list this word order as a textual variant for the Peshitta, so while we can safely conclude that this is the word order of $\mathrm{Ph}$, we cannot conclude that this word order was revised by the translator of $\mathrm{Ph}$.

The text of $\mathrm{Ph}$ also demonstrates the translation ald in place of the shorter phrase حصلm. Philoxenos quotes this portion of the text twice, and both times he uses the longer phrasing. ${ }^{186}$ This is likely an attempt to produce a word-for-word translation of the Greek, but the fact that the text of $\mathrm{H}$ includes ramplicates this explanation because the text of $\mathrm{H}$ is generally more accurate with respect to word-for-word translations than the text of $\mathrm{Ph}$. It is also possible that this translation is the result of textual variation in the Greek Vorlagen. The critical text of $\mathrm{NA}^{27}$ reads $\dot{\varepsilon} \nu \tau \tilde{\eta} \dot{\alpha} \lambda \eta \theta \varepsilon \dot{\alpha} \alpha$, but several MSS replace $\dot{\varepsilon} v$ with $\varepsilon \dot{\zeta} .^{187}$ The slight difference of

${ }^{181}$ CPJ 159.3-4; CML 9.12-13.

182 CPJ 178.11-12; CML 3.20-21.

${ }^{183}$ CPJ 159.3-4; 178.11-12.

${ }^{184}$ CML 3.20-21. This citation is quite short and should probably be considered an allusion. Thus, there is no need to postulate that the text of Ph omitted r.s.

${ }^{185}$ CML 9.12-13.

186 CML 9.12-13; CPJ 159.3-4.

187 The variant is attested by codices $\mathrm{A}$ and $\mathrm{B}$ and a few vulgate mss. Moreover, this variant was included in the text of $\mathrm{NA}^{25}$ as noted by the symbol $\dagger$ in the textual apparatus. Thus, the text of the witnesses for this variant are ancient enough to have been found in a Vorlage used by the translator of $\mathrm{Ph}$. 
nuance between these words could certainly cause a translator to

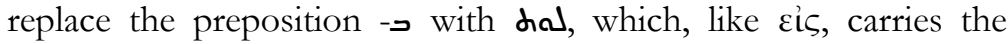
connotation of 'to, toward' rather than 'in.' Thus, we conclude that the text of $\mathrm{Ph}$ provides support for an established textual variant not found in the other Syriac versions. Moreover, it appears that the translator of $\mathrm{H}$ had access to a Vorlage that included $\dot{\varepsilon} v$ and subsequently corrected the text of $\mathrm{Ph}$.

$16: 28$

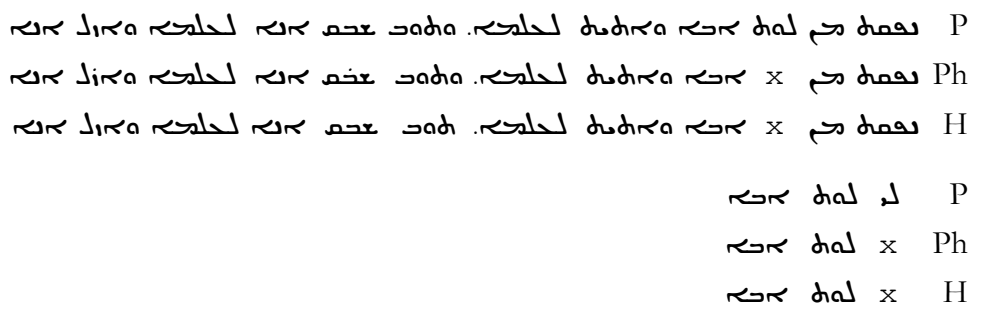

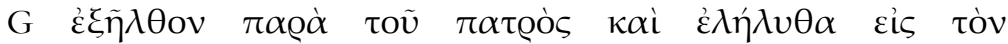

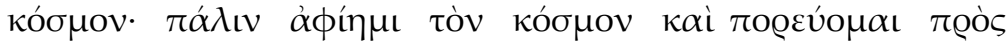

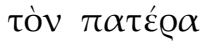

Philoxenos displays his intent to cite this verse with the citation marker 7.188 The texts of both $\mathrm{Ph}$ and $\mathrm{H}$ omit the preposition dol in the first phrase of this verse. It is possible that this revision is the result of textual variation in the Greek Vorlagen. The $\mathrm{NA}^{27}$ critical

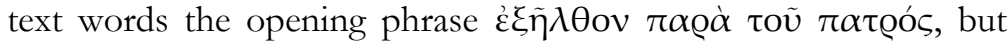
several witnesses replace $\pi \alpha \varrho \alpha$ with the preposition $\dot{\varepsilon} \kappa .{ }^{189}$ It is possible, then, that dol is a translation of $\pi \alpha \rho \alpha$ from the Greek Vorlage of the text of $\mathrm{P},{ }^{190}$ and, likewise, that the Greek Vorlagen of $\mathrm{Ph}$ and $\mathrm{H}$ read $\dot{\varepsilon} \kappa$ rather than $\pi \alpha \varrho \alpha$. This explains the absence of dal in these "word-for-word" translations. However, it is not necessary to conclude that this revision is the result of a textual variant. It is also possible that the translators of $\mathrm{Ph}$ and $\mathrm{H}$ simply omitted $h a d$ and allowed $\rightarrow$ to represent $\pi \alpha \varrho \alpha$. In the final phrase of this verse, both $\mathrm{Ph}$ and $\mathrm{H}$ omit $\lrcorner$. The inclusion of this phrase

188 CPJ 238.6-8.

189 This variant is attested by codices $\mathrm{B}, \mathrm{C}^{*}, \mathrm{~L}$, and $\Psi$, as well as a few others later mss. This variant was included in the text of $\mathrm{NA}^{25}$ as noted by the symbol $\dagger$ in the textual apparatus.

${ }^{190}$ Cf. John 1:1 for an example of hal translated from $\pi \alpha \varrho \alpha ́$. 
in the text of $\mathrm{P}$ is likely the result of the idiomatic Syriac grammatical feature known as the pleonastic dative, which emphasizes the subject of a verbal phrase by adding a personal pronoun to the preposition $-\mathrm{J}$. The translators of $\mathrm{Ph}$ and $\mathrm{H}$ omitted this phrase for the sake of literal translation of the Greek word order.

$17: 11$

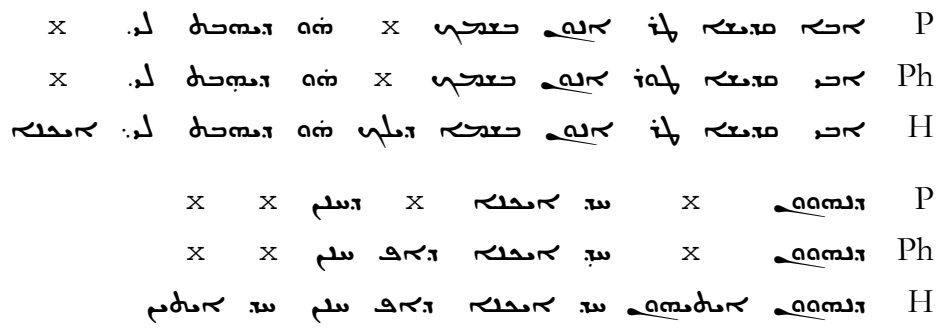

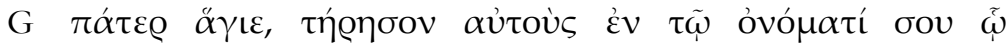

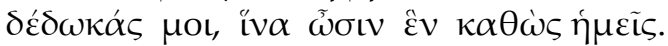

In Philoxenos' only citation of this verse, ${ }^{191}$ the text of Ph uses rather than r. It was common in early Syriac to add the first person (sg. or pl.) possessive ending to titles, such as ("lord") and ("father"). However, it is not necessary to conclude that these endings reflect a possessive pronoun in the Greek Vorlagen of these texts. ${ }^{192}$ J.P. Lyon notes, however, that idiomatically the word ک by itself implies the translation "my father."193 If Lyon's assertion is correct, then it appears that the translators of $\mathrm{Ph}$ and $\mathrm{H}$ have changed r r r in order to note the absence of a possessive pronoun, despite the fact that the opposite appears to be true. The texts of $\mathrm{Ph}$ and $\mathrm{H}$ both include the conjunction 9 r in the final phrase of the verse, but the text of $\mathrm{P}$ omits it. This discrepancy is likely based on a textual variant in the Greek

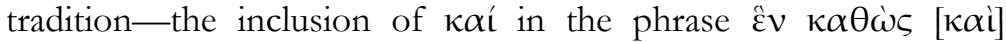
$\eta \tilde{\eta} \varepsilon \tilde{\iota} \varsigma .{ }^{194}$ Based on the existence and attestation of this variant, it

191 CPJ 210.14-15.

192 Williams, Early Syriac Translation Technique, 23-24.

${ }^{193}$ Lyon, 135-136.

194 This variant is attested by $\mathrm{P}^{107}$, codices $\mathrm{B}, \Theta$, and several other later mss and versions. 
seems reasonable to conclude that the Vorlage of the text of $\mathrm{P}$ did not include kai and the Vorlagen of $\mathrm{Ph}$ and $\mathrm{H}$ did.

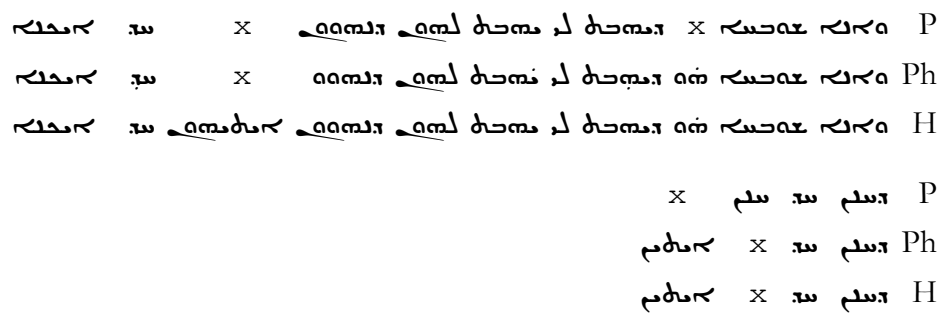

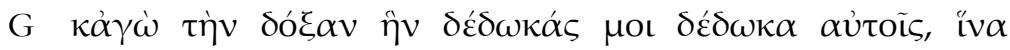

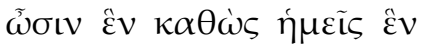

In his commentary, Philoxenos introduces this citation not with a citation marker, but with a hermeneutical paraphrase of the verse: ("And also they shall be one in us"). ${ }^{195}$ Philoxenos then quotes the verse to which he is alluding and provides the text above. The text of $\mathrm{Ph}$ includes the pronoun ari as a translation of the Greek relative pronoun pेv, and the translator of the text of $\mathrm{H}$ also includes this translation. It is likely that the translator of $\mathrm{P}$ thought that the relative pronoun $-\boldsymbol{x}$ prefixed to the next word was sufficient to carry the intended meaning, but the "word-for-word" translations of $\mathrm{Ph}$ and $\mathrm{H}$ include the additional pronoun to reflect the Greek text. In the final phrase of this verse, both $\mathrm{Ph}$ and $\mathrm{H}$ replace the first person plural pronoun w2 with the first person plural verb edur. The previous verse discussed ${ }^{196}$ ends with a phrase that is quite similar to the final phrase of this verse. The text of $\mathrm{H}$ includes the verb edur in both cases while the text of $\mathrm{Ph}$ includes it here only. This could be a case of inconsistent translation on the part of the translator of $\mathrm{Ph}$, but it is more likely that this revision is a result of a textual variant in the Greek texts. Several Greek witnesses ${ }^{197}$ include $\dot{\varepsilon} \sigma \mu \varepsilon \dot{v} v$ at the end of the sentence, precisely where the texts of $\mathrm{Ph}$ and $\mathrm{H}$ read the equivalent

195 CPJ 210.19-20. There is also an adapted allusion to this verse in CPJ 213.13-14.

${ }^{196}$ Cf. Jn. 17:11.

197 This variant is attested by corrections in $\boldsymbol{N}$ and $\mathrm{C}$, and in the original text of $\mathrm{A}, \Theta$, and $\Psi$. 
translation pdur. The existence of $\dot{\varepsilon} \sigma \mu \varepsilon \dot{v}$ in the Greek Vorlagen of $\mathrm{Ph}$ and $\mathrm{H}$ is the best explanation for the existence of pdur.

$17: 24$

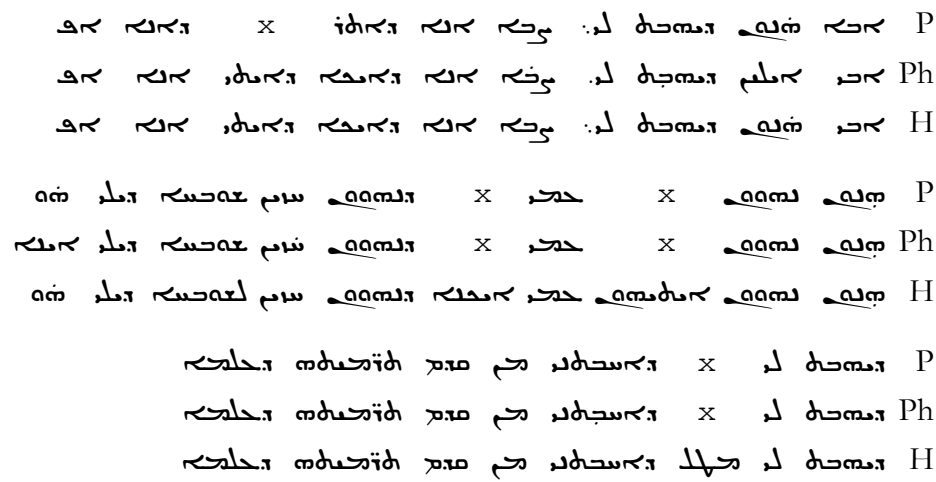

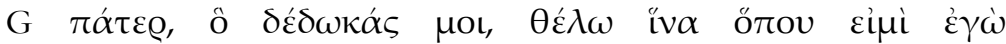

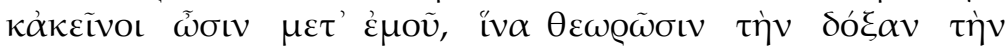

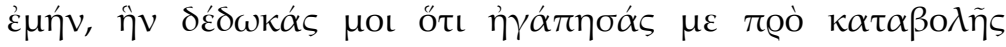

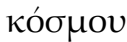

Philoxenos quotes this verse twice in CPJ, but only one citation contains the whole verse. ${ }^{198}$ As seen above in the discussion of $17: 11$, it is not necessary to consider the possessive pronoun on the first word r as a reflection of the existence of a possessive pronoun in the Greek Vorlagen. The citation of this verse shown above omits the third person plural pronoun 2 mo and adds the virtually equivalent phrase - $-\boldsymbol{x}$. It is possible that the text of $\mathrm{Ph}$ included this reading. If it is original, it seems that this variation is an attempt to translate more accurately the Greek relative pronoun of in the absence of the third person plural pronoun in the

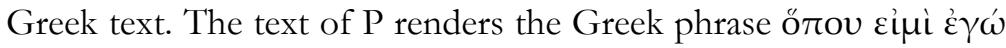
("where I am") with the phrase wri idr ("the place that I [am]"). In order to be more true to the word order of the Greek text, the

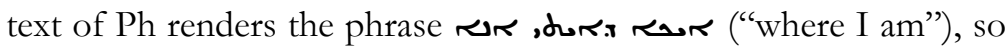
that the pronoun comes after the verb as it is in Greek. And again, the text of $\mathrm{Ph}$ replaces the third person singular pronoun an with the phrase - זrin order to more accurately translate the Greek relative pronoun $\eta v$.

${ }^{198}$ Full: CPJ 210.22-25; Partial: CPJ 59.19-20. 
$18: 8$

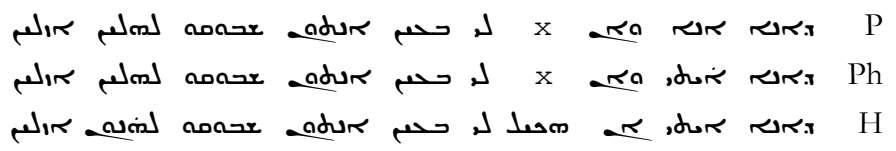

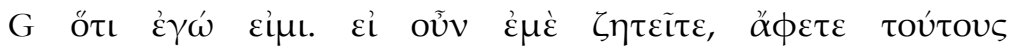

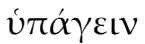

This citation ${ }^{199}$ also includes an example of a revision toward a more word-for-word translation with respect to the word order of

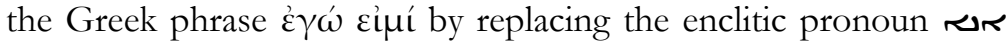
with the verbal phrase, , dor. The translator of $\mathrm{H}$ also includes this reading.

\section{CONCLUSIONS}

The primary focus of the present study has been to simply present the data for the text of the Philoxenian version for various Gospel passages as those texts can be reconstructed from the citations of Philoxenos. While this study has focused only on citations from the Gospels and presented data for only fifty-two verses, it is possible to make some tentative conclusions ${ }^{200}$ about the nature of the Philoxenian version and its place within the shifting Syriac translation technique of the sixth-century. First, we summarize briefly the types of revisions that are evident within the Philoxenian version, and then we will offer a few brief suggestions about the implications of these conclusions for the future of study with regard to the Philoxenian version.

\subsection{Revisions Characteristic of the Philoxenian Version}

Based on the revisions found in the Scripture passages presented above, it is possible to discuss a few trends of translation technique evident within the Philoxenian version. These trends include: lexical changes for more "accurate" translation, attempts at more accurate and consistent translation of verb tense, lexical omissions

${ }^{199}$ CPJ 166.11.

200 These conclusions must remain tentative until the completion of a similar project for Philoxenos' citations outside the Gospels and a more thorough comparison with other sixth-century translation projects. 
and additions based on the Greek text, and alterations in the Syriac word order to reflect the Greek.

\subsubsection{Lexical Changes for more Accurate Translations}

The most well known lexical revision in the Philoxenian version is the replacement of words built from the stem $\mathrm{x}$ in Matt 1:1 and 1:18. ${ }^{201}$ In both of these passages, Philoxenos replaces a word built from a with the word rom ("becoming, birth").202 Given his opposition to "Nestorianism," it is not surprising that Philoxenos demonstrates a strong concern for the language used in reference to Jesus' birth. ${ }^{203}$ In particular, Philoxenos seems to be concerned that speaking about the birth of Jesus might suggest that there was a change in the nature of Christ that might lead the reader to a dyophysite Christology. Thus, this lexical change is likely best explained by Philoxenos' preference for the incarnational language of the prologue of the Gospel of John in which the word "becomes" (rom) flesh. ${ }^{204}$ This seems to be the most likely explanation considering how formative Jn 1:14 is in Philoxenos' concept of the Incarnation, as evidenced by the fact that he quotes some portion of Jn 1:14 over fifty times throughout the commentaries.

201 These verses are considered together here because Philoxenos explicitly cites both in relation to the same translation issue, CPJ, 41-42.

202 However, Philoxenos does not replace every occurrence of the word with regard to Jesus' birth. Philoxenos cites Matt 1:20 four times, and three of the citations include the word aldr as a translation of the Greek $\gamma \varepsilon \nu \vee \eta \theta \dot{\varepsilon}$. The fourth citation replaces addr with durx, but this substitution appears to be the result of Philoxenos' adaptation to his writing context rather than an intentional translation change. And again in Matt 2:2, Philoxenos retains the use of the word atur in reference to Jesus.

203 However, the case of Matt 1:1 is particularly intriguing because although the word monard.x is built from the root at, the meaning of the word in this context ("descendants, generations") has nothing to do with Jesus' birth.

204 Cf. Brock, "Resolution of the Philoxenian/Harclean Problem," 329. 
There is also a fascinating example of a lexical change in Matt 16:18 in which Philoxenos preserves a reading from the Diatessaron, translating $\pi \dot{\lambda} \lambda \alpha \mathrm{L}$ as ("bars [of iron]") rather than ridh ("gates"). As noted in the discussion of this verse above, one possible explanation for the use of this translation in the Diatessaron is a christological interpretation involving Ps 107 and the "bars" of Sheol. In this interpretation, the "bars" of Sheol in Matt 16:18 are the bars that cannot withstand Jesus in the harrowing of Hell. Thus, the fact that the texts of $\mathrm{P}$ and $\mathrm{H}$ do not retain this reading begs the question of why the text of $\mathrm{Ph}$ does. Either Philoxenos (or Polycarp) had access to a copy of the Peshitta that retained this reading (which is unlikely), or Philoxenos knew of the christological interpretation of this verse and chose to include it in his new translation. 205

There are two examples in which the translator of $\mathrm{Ph}$ replaces the preposition -J ("to, for") with the independent preposition dol ("to, toward") as the translation of the Greek preposition $\pi$ @ós. ${ }^{206}$ This translation revision could be explained in one of three ways: 1) the translator has decided that dod is simply a better translation than -$\lrcorner$ based on the context; 2) the translator of $\mathrm{Ph}$ is attempting to render the Greek word order more faithfully, and the addition of dod represents Toós in the translation; or 3) perhaps it is motivated by a concern for the consistency of the translation of prepositions. The best explanation is likely is some combination of these three factors, though the third factor is perhaps the most defensible because every time the text of $\mathrm{P}$ translates $\pi$ @ós as dal, the translator of $\mathrm{Ph}$ retains dad, but every time the text of $\mathrm{P}$ translates roós as -J, the translator of $\mathrm{Ph}$ revises the text to read dal, and, moreover, when the text of $\mathrm{P}$ includes dod and there is no reós in the text, the translator of $\mathrm{Ph}$ omits dad. ${ }^{207}$

In Matt 2:6, the translator of $\mathrm{Ph}$ replaces two occurrences of the word s s" ("king") in the text of P with ("leader, ruler, governor") as a translation of the Greek word $\eta \gamma \varepsilon \mu \omega \omega v$. This appears to be a conscious attempt to retranslate the Greek because

205 For a fuller discussion of this reading, see the explanation for the text of Matt 16:18 given above.

${ }^{206}$ Cf. Lk 2:34 and 2:48

207 For examples of retaining the translation of $\mathrm{P}$, see Jn 1:1; 14:3; omitting dal, see Jn 16:28; and adding dal, see Lk 2:34 and 2:48. 


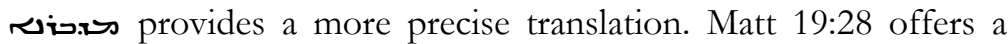
similar attempt to render Greek words consistently. The Greek word Өpóvos occurs twice in the verse, but the text of $\mathrm{P}$ uses two different words, owid ("throne"-transliterated from Greek) and reoin (also "throne"). In an attempt to make the translation consistent, the translator of $\mathrm{Ph}$ replaced owid with reoin so that both instances of Oeóvos were translated with rwin. Thus, we see an attempt on the part of the translator of $\mathrm{Ph}$ to translate Greek words more precisely and more consistently, though it is interesting to note that the text of P includes a Greek loan word and the translators of $\mathrm{Ph}$ and $\mathrm{H}$ replace the loan word with a native Syriac word.

In Luke 2:14, the translator of $\mathrm{Ph}$ replaces the word 2 (which can mean "hope, trust; thought, opinion") with sus ("will, desire"). This example is intriguing because the Greek word

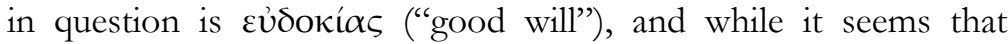
S ${ }_{5}$ is a better translation than not add an adjective to $\boldsymbol{w}_{5}$ to translate the $\varepsilon \dot{v}$-prefix. The texts of $\mathrm{P}$ (2) and $\mathrm{H}$ (hainar) both add adjectives, but it appears that the translator of $\mathrm{Ph}$ was attempting to translate عi்oкí $\alpha \varsigma$ with a one-word equivalent for the sake of matching the Greek text. Thus, we see the translator of $\mathrm{Ph}$ revising the translation of $\mathrm{P}$ in an attempt to offer a better translation and an equivalent word-forword translation of the Greek.

Matt 19:28 is an interesting example because all three versions $(\mathrm{P}, \mathrm{Ph}$, and $\mathrm{H})$ attempt to find an equivalent translation for the Greek word $\pi \alpha \lambda \imath \gamma \gamma \varepsilon v \varepsilon \sigma i ́ \alpha$ ("state of renewal; rebirth"). The translator of Ph correctly identified the first part of the Greek word compound word as $\pi \alpha \dot{\lambda} \iota v$ ("again") but mistakenly translated the second half of the word as a derivative of $\gamma \varepsilon v v \alpha \dot{\omega} \omega$ rather than

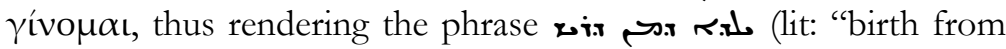
the beginning," idiomatically: "rebirth"). In this example, it is possible to see the translator of $\mathrm{Ph}$ attempting to retranslate Greek words "literally" when there is no Syriac equivalent.

\subsubsection{Translating Greek Verbs}

There are two trends in translation technique discernible in the Philoxenian version with respect to Greek verbs: replacing Syriac participles with imperfects in order to translate the Greek future 
tense and adding the preposition $\boldsymbol{n}$ to Syriac participles when translating a Greek participle. There are three examples of the translator of $\mathrm{Ph}$ retranslating Greek future tense verbs as Syriac imperfects. $^{208}$ Brock notes that the Syriac imperfect is the characteristic translation of the Greek future tense but also notes that participles are occasionally used for the future tense. ${ }^{209}$ While Syriac participles can convey the same meaning as Syriac imperfects, it appears that the translator of $\mathrm{Ph}$ is concerned not just with meaning but with rendering the tense of the Greek verbs more precisely.

It is likely that the second trend of adding $\boldsymbol{n}$ to Syriac participles ${ }^{210}$ when translating Greek participles is done for similar reasons - that is, the translator wanted to make sure that verb tenses were translated accurately. Thus, the translator of $\mathrm{Ph}$ seems to demonstrate the following technique with regard to Greek verbs:

Greek future $=$ Syriac imperfect and not Syriac participles

Greek participle $=$ Syriac participle + ה

Another trend in the translation technique of $\mathrm{Ph}$ with regard to verbs is the consistent use of the verbal phrase - dur + personal pronoun when translating forms of eijú. ${ }^{211}$ There are at least eighteen examples of this trend, though there are variations of how this translation is implemented depending on which form of $\varepsilon i \mu t$ is being translated. However, the translator of $\mathrm{Ph}$ is quite consistent with this technique. The following list provides the Greek form of

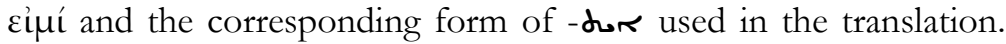
The footnote supplied offers the texts in which these examples are found.

208 Matt 3:12; 10:17; 11:27.

${ }^{209}$ Brock, "Limitations of Syriac," 90-91.

${ }^{210}$ Matt 2:2; John 1:15.

${ }^{211} \mathrm{D}$. King also notes this is a translation technique evident in Quod Unus sit Christus and Responsiones ad Tiberium, King, Cyril of Alexandria, 106, 117. 


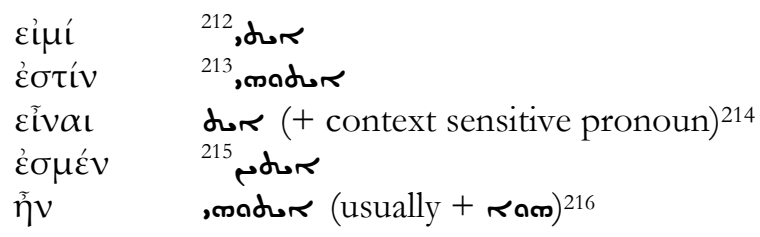

Given the frequency and the consistency of the examples above, we can see that the translator of the text of $\mathrm{Ph}$ consistently translates forms of the Greek verb cijui with forms of -dur when the text of P translates the text in idiomatic Syriac with either the use of an absolute state noun in the predicate position ${ }^{217}$ or the enclitic use of ram. ${ }^{218}$

\subsubsection{Word Order}

This category includes revisions pertaining to the order of the words found in the Syriac translation and the corresponding order of words in the Greek texts. This category includes moving the particles to reflect the placement of equivalent particles in the Greek word order such as e.r, ${ }^{219}$ prepositional phrases, ${ }^{220}$ and the the order of subject/verb/object phrases.221 Other than the examples just provided, there are at least eight more examples of the translator of $\mathrm{Ph}$ changing the word order of the Syriac translation in order to make it more "literal" with respect to the word order of the Greek text. ${ }^{222}$

${ }^{212}$ Jn $3: 28 ; 17: 24 ; 18: 8$.

${ }^{213}$ Matt 1:23; 2:2; Jn 1:33.

${ }^{214}$ Lk 2:6; 3:23.

215 Jn 17:22.

${ }^{216}$ Matt 1:18; Jn 1:8, 10, 15 (twice). In three of the five instances ram is also included.

217 See T. Nöldeke, Compendious Syriac Grammar, trans. and ed. by James A. Crichton (Winona Lake: Eisenbrauns, 2001) \204, 158-159.

218 Ibid., \299, 238-239.

${ }^{219}$ Matt 1:18.

${ }^{220}$ Matt 1:20; Lk 2:14.

${ }^{221}$ Lk 1:35; Jn 12:26; 16:13.

222 Matt 2:1; Lk 2:43; John 1:10, 15, 17, 33; 14:3; $18: 8$. 


\subsubsection{Omissions}

This category refers to the instances in which the translator of $\mathrm{Ph}$ omits words found in the translation of $\mathrm{P}$ based on the wording of the Greek text. There are at least seven examples of this category, but it includes only minor omissions such as particles ( $\mathrm{r}^{223}$ and in ${ }^{224}$ ), pronouns (relative and personal), ${ }^{225}$ and prepositions. ${ }^{226}$ This category represents a conscious effort on the part of the translator of $\mathrm{Ph}$ to render the Greek text more "literally" by omitting words not found in the Greek text.

\subsubsection{Additions}

This category overlaps with the above discussion of the translation of $\varepsilon i \mu i$ as the translator of $\mathrm{Ph}$ frequently adds the word -dor when the meaning is merely implied in the translation of P. This category also includes prepositions and prepositional phrases, ${ }^{227}$ nouns, ${ }^{228}$ pronouns, ${ }^{229}$ and verbs. ${ }^{230}$ In addition to the examples just mentioned, there are at least seven more examples of the translator of $\mathrm{Ph}$ making additions to reflect the presence of words in Greek. 231

\subsection{Implications of the Present Study for Future Scholarship}

The intent of the present study has been to present the data for the unique readings of the Gospels of the Philoxenian version as reconstructed from the exegetical writings of Philoxenos. The results of this study confirm the resolution of the Philoxenian/Harclean problem as concluded by Sebastian Brock: the Philoxenian version is a distinct translation from both the Peshitta and the Harclean version. Moreover, it is clear that the translation technique evident throughout the citations discussed

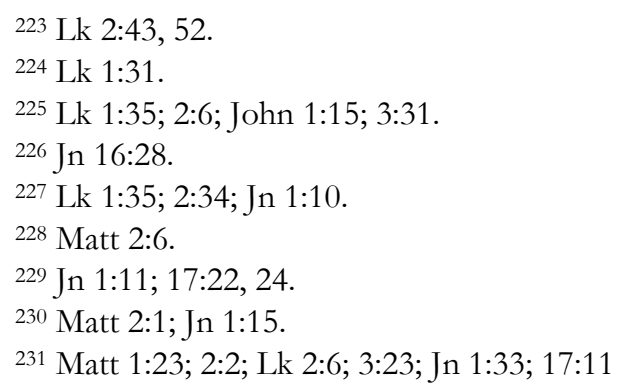


here fits well within what we already know about Greek-to-Syriac translation technique in the sixth-century: there was an intentional movement toward a more word-for-word translation, but this technique was very much still in flux throughout the sixth-century until the creation of the hyper literal Harclean version in the early seventh-century.

The reconstruction of the Philoxenian version of the New Testament is by no means completed, as the project encompasses only the Gospels. Hopefully the present project will serve as a model by which further inquiry can be made into the Philoxenian text of the NT documents outside the Gospels and as an aide in our broader understanding of sixth-century translation technique.

\section{BIBLIOGRAPHY}

\section{Primary Sources for Philoxenos}

De Halleux, André. Eli de Qartamin: Memra sur Mar Pbiloxìne de Mabbog. CSCO 233, 234. Louvain: Secrétariat du CorpusSCO, 1963. - Philoxène de Mabbog: Commentaire du prologue johannique (Ms. Br. Mus. Add. 14,534). CSCO 380, 381. Louvain: Secrétariat du CorpusSCO, 1977.

. Philoxène de Mabbog: Lettre aux moines Senoun, CSCO 231, 232. Louvain: Secrétariat du CorpusSCO, 1963.

Vaschalde, A. Pbiloxeni Mabbugensis: Tractatus Tres de Trinitate et Incarnatione. CSCO 9, 10. Louvain: Secretariat du CorpusSCO, 1907.

Watt, J. W. Pbiloxenos of Mabbug: Fragments of the Commentary on Matthew and Luke. CSCO 392, 393. Louvain: Secrétariat du CorpusSCO, 1978.

\section{Other Sources}

Aland, Barbara and A. Juckel, eds. Das Neue Testament in Syrischer Überlieferung, Die Paulinischen Briefe, 3 Vols. Berlin: Walter de Gruyter, 1991, 1995, 2002.

- "Die Philoxenianisch-harklensische Übersetzungstradition: Ergebnisse einer Untersuchung der neutestamentlichen Zitate in der syrischen Literatur." Le Muséon 94 (1981): 321-383.

Baumstark, Anton. Geschichte der syrischen Literatur. Bonn, 1922.

Brock, Sebastian. "Aspects of Translation Technique in Antiquity." Pages 69-87 in Greek, Roman and Byzantine Studies XX. Durham, 1979. 
Repr. in Brock, Syriac Perspectives on Late Antiquity. London: Variorum Reprints, 1984.

Brock, Sebastian. The Bible in the Syriac Tradition. Piscataway, NJ: Gorgias Press, 2006.

. "The Christology of the Church of the East." Pages 159-179 in Traditions and Heritage of the Christian East. Edited by D. Afinogenov and A. Muraviev. Moscow: Izdatelstvo, 1996. Repr. in Repr. in Brock, Fire from Heaven: Studies in Syriac Theology and Liturgy. Burlington: Ashgate Publishing Company, 2006.

. "Come, Compassionate Mother..., Come Holy Spirit': A Forgotten Aspect of Early Eastern Christian Imagery," Aram 3 (Oxford, 1991), 249-257; Repr. in Brock, Fire From Heaven: Studies in Syriac Theology and Liturgy. Burlington: Ashgate Publishing, 2006.

. "Greek and Syriac in Late Antique Syria." Pages149-160 in Literacy and Power in the Ancient World. Edited by A.K. Bowman and G. Woolf. Cambridge, 1994. Repr. in Brock, From Ephrem to Romanos: Interactions between Syriac and Greek in Late Antiquity. Burlington: Ashgate Publishing, 1999.

. "Greek into Syriac and Syriac into Greek." Journal of the Syriac Academy III. Baghdad (1979), 1-17. Repr. in Brock, Syriac Perspectives on Late Antiquity. London: Variorum Reprints, 1984.

. "Greek Words in Syriac: Some General Features." Studia Classica Israelica 15. Jerusalem, 1996: 251-262. Repr. in Brock, From Ephrem to Romanos: Interactions between Syriac and Greek in Late Antiquity. Burlington: Ashgate Publishing, 1999.

. "Limitations of Syriac in Representing Greek." Pages 83-98 in The Early Versions of the New Testament: Their Origin, Transmission, and Limitations. By Bruce Metzger. Oxford: Clarendon Press, 1977.

. "The 'Nestorian' Church: A Lamentable Misnomer.” Pages 2335 in The Church of the East: Life and Thought. Edited by J.F. Coakley and K. Perry. Bulletin of the John Rylands University Library of Manchester 73:3, 1996. Repr. in Brock, Fire from Heaven: Studies in Syriac Theology and Liturgy. Burlington: Ashgate Publishing Company, 2006. and M. A. Mathai Remban. Pbiloxenos of Mabbug. SEERI Correspondence Course 9. Kerala: St. Ephrem Ecumenical Research Institute, 1989. 
Brock, Sebastian. "The Resolution of the Philoxenian/Harklean Problem." Pages 325-343 in E. J. Epp and G. D. Fee, eds., New Testament Textual Criticism: Its Significance for Exegesis: Essays in Honour of Bruce M. Metzger. Oxford: Clarendon Press, 1981.

. "Some Aspects of Greek Words in Syriac." Pages 80-108 in Synkretismus im syrisch-persischen Kulturgebeit. By A. Dietrich. Göttingen: Vandenhoeck and Ruprecht, 1975. Repr. in Brock, Syriac Perspectives on Late Antiquity. London: Variorum Reprints, 1984.

. "The Syriac Background to Hunayn's Translation Techniques." Aram 3, Oxford, 1991. Repr. in Brock, From Ephrem to Romanos: Interactions between Syriac and Greek in Late Antiquity. Burlington: Ashgate Publishing, 1999.

. "Towards a History of Syriac Translation Technique." Pages 1-14 in III Symposium Syriacum 1980: Les contacts du monde syriaque avec les autres cultures. By René Lavenant. Rome: Pont. Institutum Studiorum Orientalum, 1983.

Burkitt, F.C. Evangelion da-Mepharreshe. The Cruetonian Version of the Four Gospels, with the Readings of the Sinai Palimpsest and the early Syriac Patristic Evidence. 2 vols. Cambridge: University Press, 1901.

De Halleux, André. Philoxène de Mabbog: sa vie, ses écrits, sa théologie. Louvain: Imprimerie Orientaliste, 1963.

Fee, Gordon D. "The Use of Greek Patristic Citations in New Testament Textual Criticism.” ANRW 26.1 (1992): 256-62.

Guidi, I. "La lettera di Filosseno ai monaci di Tell'adda-Teleda," Atti della Reale Accademia dei Lincei, Serie 3 (Memorie, 1884).

Gwynn, John. The Apocalypse of St. John in a Syriac Version bitherto unknown. Dublin: Hodges, Figgis, and Co., 1987. Reprinted, Amsterdam: Philo Press, 1981; Piscataway: Gorgias Press, 2005.

- Remnants of the Later Syriac Versions of the Bible. Piscataway: Gorgias Press, 2005.

Hatch, William H. P. "The Subscription of the Chester Beatty Manuscript of the Harclean Gospel," The Harvard Theological Review 30, no. 3 (Jul. 1937): 141-155.

Hill, Peter A. L. "Matthew 16:18 in the Philoxenian Version." TC: A Journal of Biblical Textual Criticism, 13, 2008. Available at URL: http://rosetta.reltech.org/TC/vol13/Hill20008.pdf.

Kiraz, George A. Comparative Edition of the Syriac Gospels: Aligning the Sinaiticus, Curetonianus, Peshitta and Harklean Versions, 4 Vols. Piscataway: Gorgias Press, 2004. 
Lyon, Jeffery P. Syriac Gospel Translations: A Comparison of the Language and Translation Method Used in the Old Syriac, The Diatessaron, and The Peshitto. CSCO 548, Sub. 88. Louvain: Peeters, 1994.

Metzger, Bruce M. The Early Versions of the New Testament: Their Origin, Transmission, and Limitations. Oxford: Clarendon Press, 1977.

Michelson, David. "Practice Leads to Theory: Orthodoxy and the Spiritual Struggle in the World of Philoxenos of Mabbug (470523)." Ph.D. Dissertation, Princeton University, 2007.

Murray, Robert. "The Rock and the House on the Rock. A Chapter on the Ecclesiastical Symbolism of Aphrahat and Ephraem." Orientalia Christiana Periodica 30 (1964): 315-362.

Nöldeke, T. Compendious Syriac Grammar. Translated and edited by James A. Crichton. Winona Lake: Eisenbrauns, 2001.

Osburn, Carroll D. "Methodology in Identifying Patristic Citations in NT Textual Criticism." NovT 47, no. 4 (2005): 313-343.

Pusey, P. E. and G. H. Gwilliam, eds. Tetraenangelium Sanctum. Oxford: The Clarendon Press, 1901. Reprinted as Tetraenangelium Sanctum: The Fourfold Holy Gospel in the Peshitta Syriac Version with Critical Apparatus. Piscataway: Gorgias Press, 2003.

Romeny, Bas ter Haar. "A Philoxenian-Harclean Tradition? Biblical Quotations in Syriac Translations from Greek." Pages 59-76 in Wout Jac. van Bekkum, Jan Willem Drijvers and Alex C. Klugkist, Syriac Polemics: Studies in Honour of Gerrit Jan Reinink. Louvain: Peeters, 2007.

Smith, J. Payne, ed. A Compendious Syriac Dictionary. Eugene: Wipf and Stock, 1999.

Van Rompay, Lucas. "Bardaisan and Mani in Philoxenos of Mabbog's Memre Against Habbib. Pages 77-90 in The Peshitta: Its Use in Literature and Liturgy: Papers Read at the Third Pesbitta Symposium. Edited by Bas ter Haar Romeny. Monographs of the Peshitta Institute Leiden 15. Leiden: Brill, 2006.

Vööubs, Arthur. Early Versions of the New Testament: Manuscript Studies. Papers of the Estonian Theological Society in Exile, no. 6. Stockholm, 1954.

- "New Data for the Solution of the Problem Concerning the Philoxenian Version," in Spiritus et veritas: Festschrift Karl Kundrins. Eutin: A. Ozolins, 1953.

White, Joseph. Sacrorum Evangeliorum versio Syriaca Pbiloxeniana cum interpretatione et annotationibus. Oxford: Clarendon, 1778. 
Williams, P. J. Early Syriac Translation Technique and the Textual Criticism of the Greek Gospels. Texts and Studies, Third Series, vol. 2. Piscataway: Gorgias Press, 2004.

Zuntz, G. The Ancestry of the Harklean New Testament. British Academy Supplemental Papers, no. 7. London: The British Academy, 1945. 
